\title{
High 1,4-syn-induction in the addition of chiral allyltrichlorostannanes to chiral aldehydes
}

\author{
Luiz C. Dias,* Rosana Giacomini, Paulo R. R. Meira, Edílson Ferreira, \\ Andréa A. Ferreira, Gaspar Diaz, Débora R. dos Santos, and Leonardo J. Steil \\ Instituto de Química, Universidade Estadual de Campinas, UNICAMP \\ C.P. 6154, 13084-971, Campinas, SP, Brazil \\ E-mail: ldias@iqm.unicamp.br
}

Dedicated to Prof. Edmundo A. Ruveda on the occasion of his $70^{\text {th }}$ birthday

(received 09 Aug 03; accepted 18 Sep 03; published on the web 24 Sep 03)

\begin{abstract}
Chiral and achiral allyltrichlorostannanes reacted with chiral aldehydes to give the corresponding homoallylic alcohols with good to high diastereoselectivities. This approach has been applied to the synthesis of hydroxyethylene dipeptide isosteres L-682, 679, L-684,414, L-685,434 and L685,458 .
\end{abstract}

Keywords: Allylsilanes, allyltrichlorostannanes, chiral aldehydes, ligand exchange reactions

\section{Introduction}

The Lewis-acid mediated reaction of allylsilanes and allylstannanes with aldehydes is a wellknown procedure for the preparation of homoallylic alcohols. ${ }^{1,2}$ The stereochemical outcome of this reaction has on occasion been explained by considering Lewis acid-carbonyl complexation. This type of complexation mainly occurs by two discrete pathways, chelation and non-chelation controlled, depending on the nature of the Lewis acid and on the steric requirements of the carbonyl ligand. Condensation of allylic metals (e.g M: Si, Ti, Sn. B, Cr) with various carbonyl compounds can be used to achieve acyclic stereoselection, and has been applied to the synthesis of natural products. ${ }^{3,4}$ Chiral allylmetal reagents may be thought of as acetate-enolate equivalents for diastereoselective construction of stereochemically well-defined homoallylic alcohols. As these reactions complement the aldol reactions, allylsilanes and allylstannanes are among the most important groups of organometallic type reagents available for the control of acyclic stereochemistry. ${ }^{1,4}$ Many methods can be used to control the configurations of stereogenic centers that are close to each other. However, relatively few methods are available for control of the stereochemistry of more remote stereocenters. 
This account focuses on our recent work on the chemistry of allylsilanes and allyltrichlorostannanes. We believe this chemistry may be very useful for the synthesis of compounds with remote stereogenic centers and is reviewed in this article.

\section{NMR study on ligand exchange reactions between allylsilanes and $\mathrm{SnCl}_{\mathbf{4}}$}

We began this work a few years ago, with a spectroscopic study $\left({ }^{1} \mathrm{H},{ }^{13} \mathrm{C}\right.$, and $\left.{ }^{119} \mathrm{Sn} \mathrm{NMR}\right)$ of the reactions of allylsilanes $\mathbf{1}, 3$ and 5 with $\mathrm{SnCl}_{4}$ (Scheme 1). ${ }^{5,6}$ Allylsilanes $\mathbf{1}, 3$ and 5 and $\mathrm{SnCl}_{4}$ (0.5 $\mathrm{M}$ solution in $\mathrm{CDCl}_{3}$ ) were mixed in order to promote ligand exchange, leading to the corresponding allyltrichlorostannanes $2, \mathbf{4}$ and $\mathbf{6}$, respectively. ${ }^{6-10}$

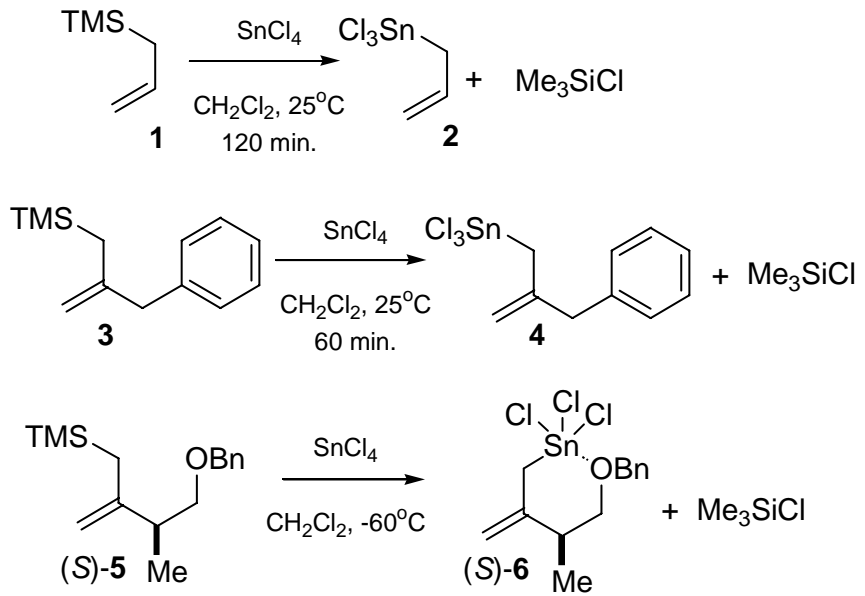

\section{Scheme 1}

For allyltrimethylsilane $\mathbf{1}$ the ligand exchange producing allyltrichlorostannane $\mathbf{2}$ and $\mathrm{Me}_{3} \mathrm{SiCl}$ is complete after 120 minutes at room temperature (Scheme 1). For allylsilane 3 the metathesis to give 4 and $\mathrm{Me}_{3} \mathrm{SiCl}$ is faster, as expected for a 1,1-disubstituted olefin, being complete after 60 minutes at room temperature. ${ }^{6}$ Upon addition of $\mathrm{SnCl}_{4}$ to a solution of allylsilane (S)-5 in $\mathrm{CDCl}_{3}$, at $-60{ }^{\circ} \mathrm{C}$, as well as at room temperature, a slightly yellow homogeneous solution was obtained. The resulting NMR spectrum at $-60{ }^{\circ} \mathrm{C}$ showed formation of $\mathrm{Me}_{3} \mathrm{SiCl}$ and complete consumption of the allylsilane $(S)-5$ within 1 minute to give allyltrichlorostannane $(S)$-6. It appears that the oxygen functionality is responsible for the rapid ligand exchange reaction observed even at low temperatures for this particular allylsilane and $\mathrm{SnCl}_{4}$. The ligand exchange reaction is probably facilitated by coordination of tin to this oxygen followed by cleavage of the carbon-silicon bond by a free chloride ion.

Most diagnostics is the deshielding of the hydrogens $\mathrm{H} 1$ to $\mathrm{H} 6$ in the ${ }^{1} \mathrm{H}$ NMR spectrum of (S)-6 (Figure 1). The methylenic hydrogens $\mathrm{H} 3$ and $\mathrm{H} 4$ as well as the benzylic hydrogens $\mathrm{H} 5$ and H6 are too far away from trichlorotin group to suffer from inductive effects. We believe that the deshielding observed for these hydrogens is due to the internal coordination of this oxygen to tin, as proposed in Figure 1. ${ }^{6}$ 

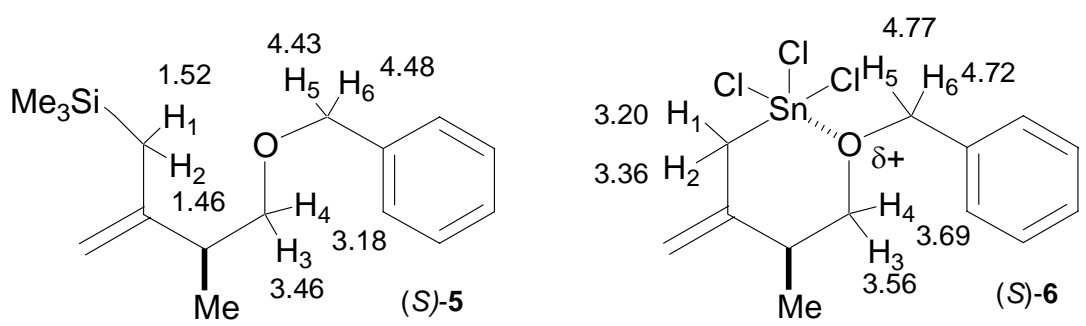

\section{Figure 1}

Analysis of the ${ }^{13} \mathrm{C}$ NMR spectrum showed a deshielding for most carbons of (S)-6 when compared to allylsilane (S)-5 (Figure 2). Most diagnostic is the chemical shift of $39.95 \mathrm{ppm}$ for the carbon attached to tin in the new species, compared to $26.63 \mathrm{ppm}$ for the same carbon in the allylsilane. ${ }^{6}$
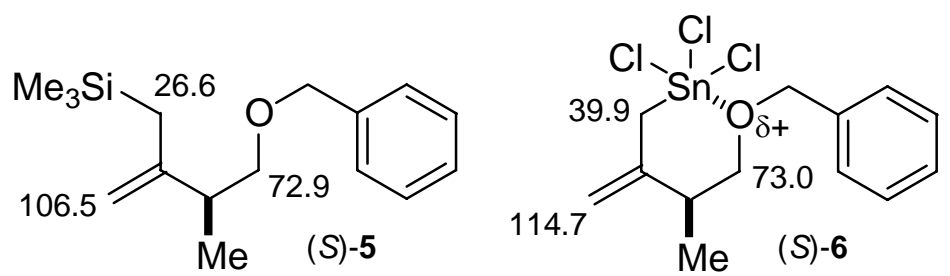

\section{Figure 2}

The ${ }^{13} \mathrm{C}$ NMR spectra proved less useful than the ${ }^{1} \mathrm{H}$ NMR spectra in establishing complexation to the benzyl oxygen, as there was no significant difference between the chemical shifts for methylenic carbons in both species.

We have observed ${ }^{119} \mathrm{Sn}$ resonance signals at $-27 \mathrm{ppm}$ for allylstannanes 2 and $4 .{ }^{6}$ The tin chemical shift for allylstannane 6 appeared at $-187 \mathrm{ppm}$. We believe that tin chemical shifts are highly sensitive to oxygen bonding, and this is strong evidence in favor of the complexed intermediate.

\section{Allyltrichlorostannane additions to mono and disubstituted aldehydes}

The next step involved the reaction between chiral $\alpha$-substituted aldehydes and allylstannane $(R)$-6 (Scheme 2). These substrates have been selected to be representative of the complex fragments that might be coupled in polyacetate and polypropionate-derived aldol-type reactions. $^{11}$

The in situ prepared allylstannane $(R)-6$ reacted with aldehyde $(R)-7$ to give a mixture of 1,4syn and 1,4-anti-diastereomers with 92:08 diastereoselectivity, favoring the 1,4-syn-isomer 8 with Felkin addition (Scheme 2). ${ }^{11,12}$ It should be noted that this reaction gives a very important subunit with different protecting groups at both termini and a double bond that can be further manipulated to a carbonyl group and then selectively reduced to the 1,3-syn and 1,3-anti diol functionalities. 


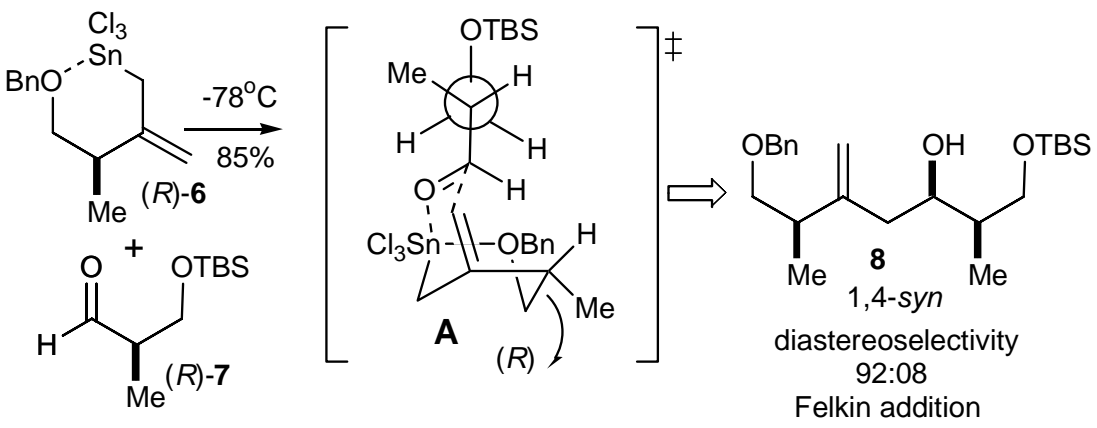

\section{Scheme 2}

Under the same conditions, allyltrichlorostannane $(R)-6$ reacted with aldehyde $(S)-7$ to give 1,4-syn-product 9 as the major isomer, with anti-Felkin addition (Scheme 3). ${ }^{11,12}$

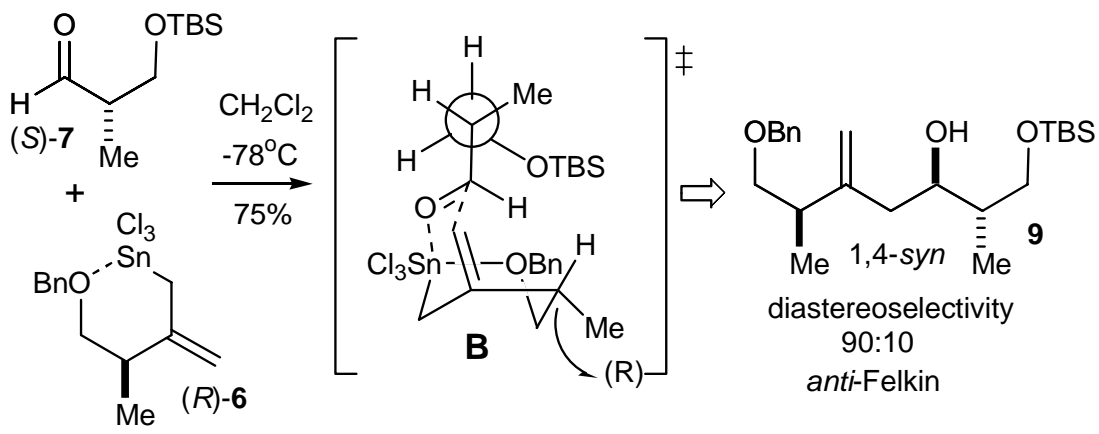

\section{Scheme 3}

The stereoselectivity of the reactions of allyltrichlorostannane $(R)-6$ with aldehydes $(R)-7$ and (S)-7 is consistent with an intermediate allyltin trichloride, which is stabilized by tin-oxygen interaction. A boat-like arrangement is proposed, as it avoids steric interactions between the aldehyde substituents and the axial methyl group $\alpha$ to the double bond in the chair structure (transition states $\mathbf{A}$, Scheme 2 and $\mathbf{B}$, Scheme 3). This complex intermediate then reacts with the aldehyde via chair-like six-membered ring transition states ( $\mathbf{A}$ and $\mathbf{B}$ ) in which the aldehyde approaches the complex opposite to the methyl group. The preference of the alkyl group of the aldehyde to adopt an equatorial position controls the aldehyde facial selectivity, resulting in the favored 1,4-syn stereochemistry in the adduct, independent of the aldehyde absolute configuration.

These examples shown that the levels of $\pi$-facial selection are independent of the absolute stereochemistry of the $\alpha$-methyl substituted aldehydes and support the notion that the stereocenter in allyltrichlorostannane is primarily responsible for the observed diastereoselection. ${ }^{6}$

We investigated the reaction between chiral $\beta$-alkoxy as well as $\alpha$-methyl- $\beta$-alkoxy aldehydes with achiral and chiral allyltrichlorostannanes. ${ }^{13}$ This study details our efforts to 
understand the double stereodifferentiating stereocontrol elements involved in chiral allyltrichlorostannane additions to chiral $\beta$ - and $\alpha, \beta$-disubstituted aldehydes. In this part of the investigation, we have examined the interplay between 1,2- (Felkin-Anh), 1,3- and 1,4asymmetric induction in allyltrichlorostannane reactions with $\beta$-alkoxy and $\alpha$-methyl- $\beta$-alkoxy aldehydes under conditions that preclude internal chelation with the aldehyde $\beta$-alkoxy substituent.

In order to check the facial selectivity of aldehyde $(S)$-10 we reacted it first with achiral allyltrichlorostannane 4 (Scheme 4). ${ }^{13}$

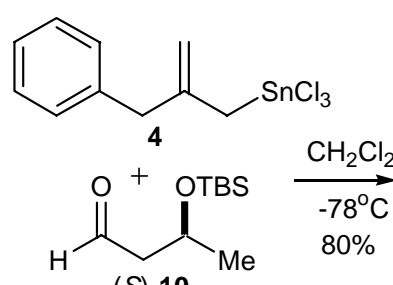

(S)-10
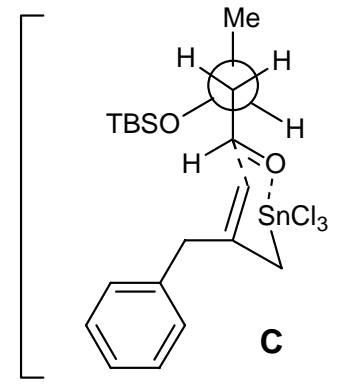

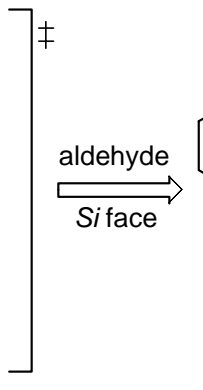

\section{Scheme 4}

Achiral allyltrichlorostannane 4 reacted with chiral $\beta$-alkoxy aldehyde $(S)$-10 in $\mathrm{CH}_{2} \mathrm{Cl}_{2}$ at $78{ }^{\circ} \mathrm{C}$ to give the corresponding 1,3-anti product $\mathbf{1 1}$ as the major product in good yield and with 78:22 diastereoselectivity (Scheme 4 ). ${ }^{13}$ The stereoinduction observed in this reaction indicates that the intrinsic facial bias imposed by the resident $\beta$-OTBS substituent results in preferential formation of the 1,3-anti diastereomer, with a preference for aldehyde si-face attack. In the proposed transition state conformation (C), steric interactions are expected to be reduced when the $\beta$-Me substituent in this aldehyde is placed anti to the $\mathrm{C} \alpha-\mathrm{C}=\mathrm{O}$ bond (Scheme 4). In this conformation we might expect also minimization of destabilizing dipole interactions since the $\beta$ OTBS group and $\mathrm{C}=\mathrm{O}$ are oriented in opposite directions. A chair-like transition state $(\mathbf{C})$ with the alkyl group of the aldehyde in an equatorial position and with attack to the si-face of the aldehyde, explains the observed sense of induction.

Under the same conditions allyltrichlorostannane $(S)-\mathbf{6}$ reacted with aldehyde $(S)-\mathbf{1 0}$ to give 1,3-anti-1,4-syn product 12 as the major product (85:15 diastereoselectivity) (Scheme 5). ${ }^{13}$ As we know from previous work that the facial bias of this chiral allyltrichlorostannane is dominated by the $\alpha$-methyl stereocenter and tends to give the 1,4-syn isomer with si-face attack, and aldehyde $(S)$-10 has a preference to give the 1,3-anti product, this is an example of a matched reaction. 


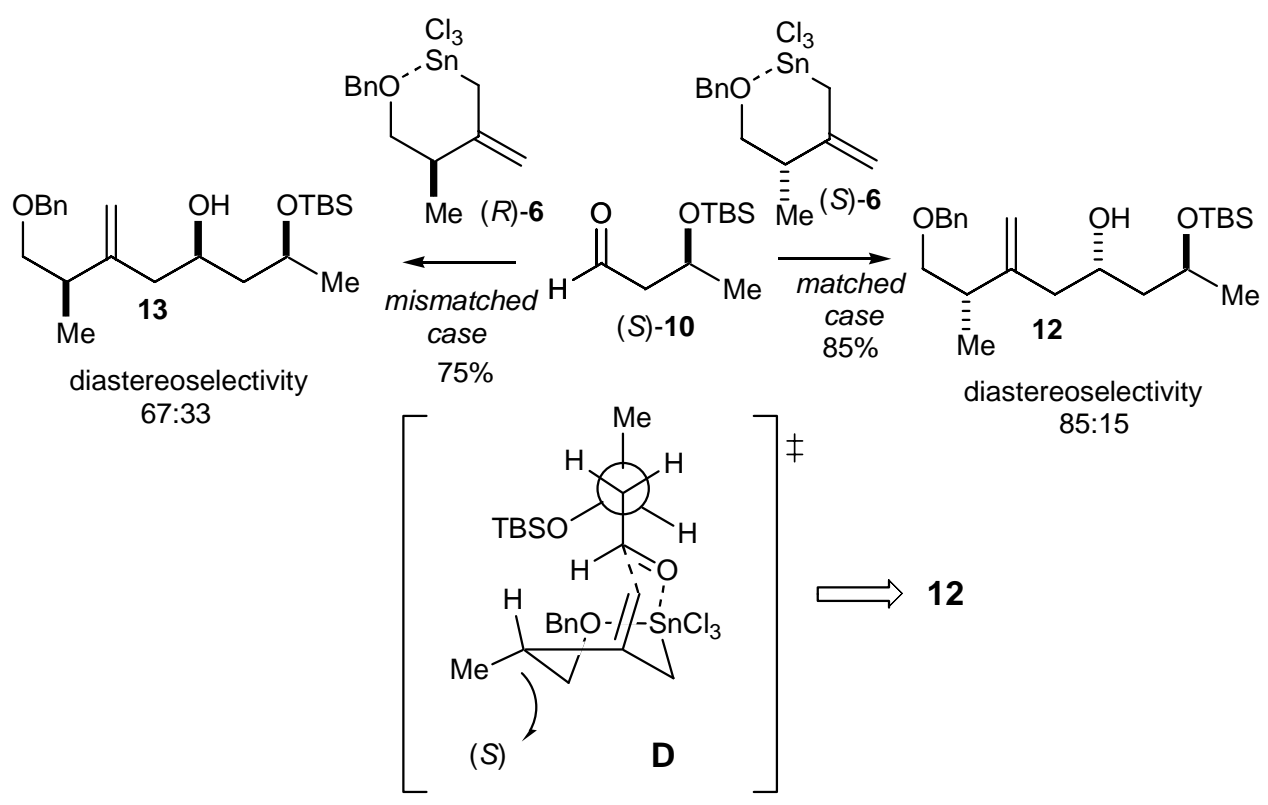

\section{Scheme 5}

The stereoselectivity of this reaction is consistent with an intermediate allyltin trichloride which is stabilized by tin-oxygen interaction, and which then reacts with the aldehyde via a chair-like six-member ring transition state (D) in which the aldehyde approaches the boat-like complex opposite to the methyl group (Scheme 5). Again, a boat-like arrangement is proposed, as it avoids steric interactions between the aldehyde substituents and the axial methyl group $\alpha$ to the double bond in the chair structure.

Addition of the enantiomeric allyltrichlorostannane $(R)-6$ to aldehyde $(S)-10$ led to a 67:33 mixture favoring the 1,4-syn-1,3-syn product 13, in a mismatched case (Scheme 5). ${ }^{13}$

We next examined the stereochemical impact of both $\alpha$ and $\beta$-aldehyde substituents using chiralsyn and anti disubstituted $\alpha$-methyl- $\beta$-alkoxy aldehydes. ${ }^{13-15}$

Achiral allyltrichlorostannane 4 reacted with chiral syn- $\alpha, \beta$-disubstituted ${ }^{14}$ aldehyde $\mathbf{1 4}$ to give the corresponding 1,2-syn-1,3-syn product 15 in 92\% yield and with 96:04 diastereoselectivity (Scheme 6).
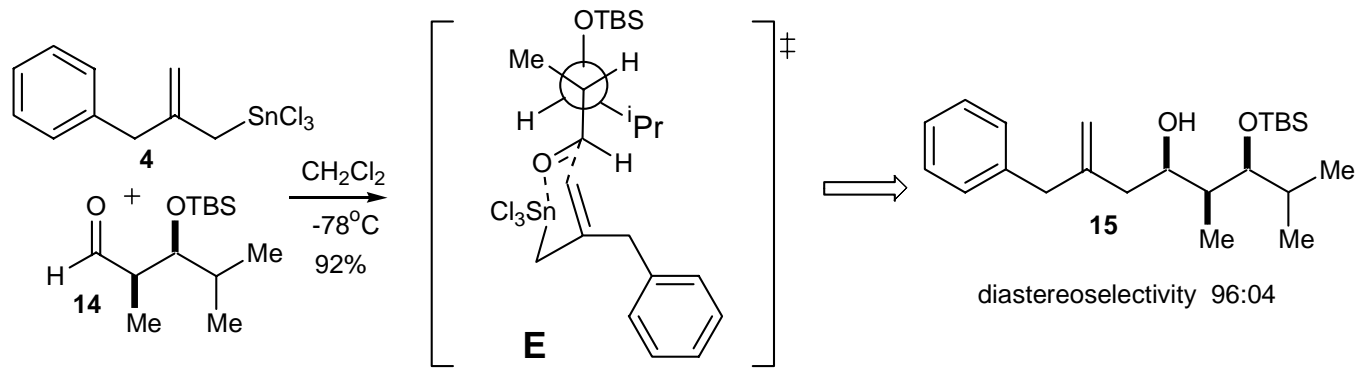

\section{Scheme 6}


This example shows that a 1,2-syn aldehyde has a preference to give the product with Felkin addition as well as 1,3-syn addition. ${ }^{13}$ In the presence of an $\alpha$-methyl stereocenter, 1,3asymmetric induction imposes an intrinsic facial bias on the carbonyl that results in the formation of the 1,3-syn-dioxygen relationship.

A chair-like transition state (E) with attack to the re-face of the aldehyde (Felkin addition), explains the observed induction direction (Scheme 6).

The reaction of chiral allyltrichlorostannane $(R)-\mathbf{6}$ with aldehyde 16 gives homoallylic alcohol 17 (all-syn product) as the major isomer (Felkin addition, matched case) (Scheme 7).

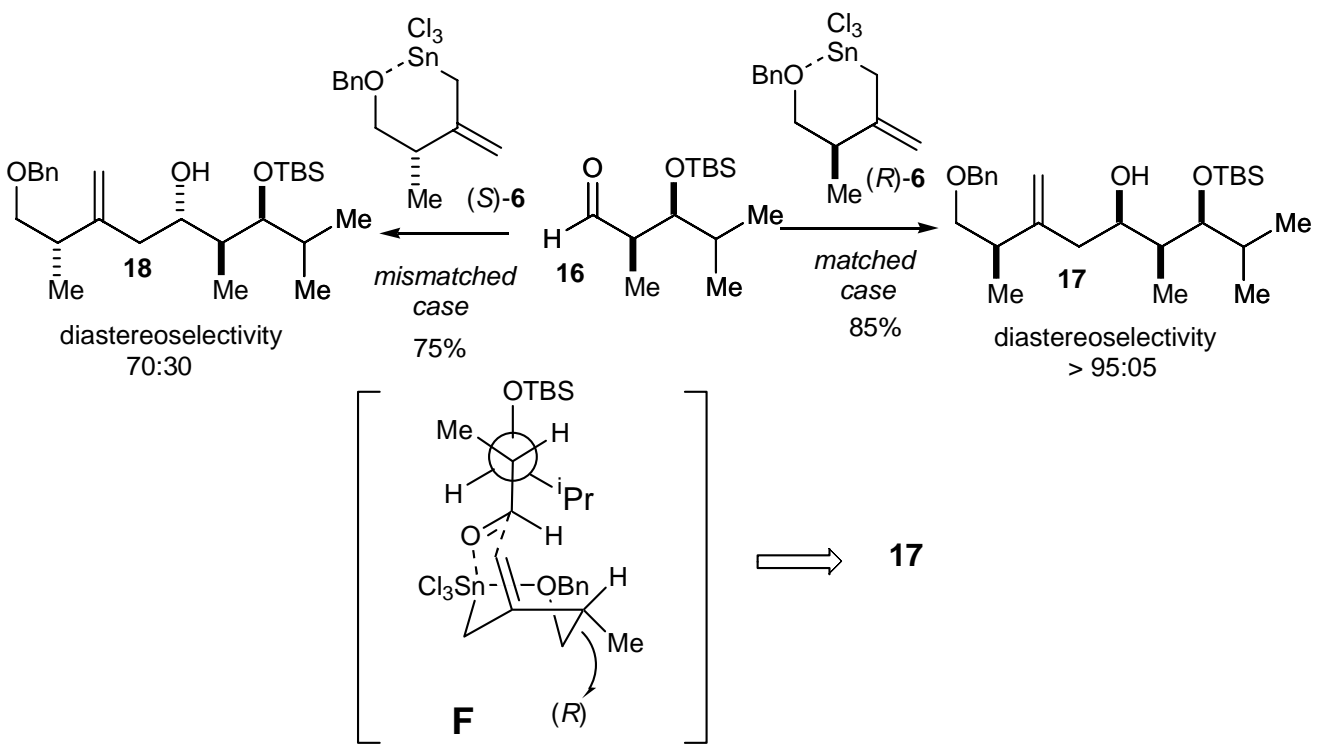

\section{Scheme 7}

The stereoselectivity of this reaction is consistent with a chair-like six-membered ring transition state $(\mathbf{F})$ in which the aldehyde approaches the boat-like allyltin complex opposite to the methyl group (Scheme 7).

Allyltrichlorostannane (S)-6 reacted with aldehyde $\mathbf{1 6}$ to give a 70:30 ratio favoring isomer 18, in a mismatched case (Scheme 7). In this latter case, the $\alpha$-methyl stereocenter in allyltrichlorostannane (propensity for 1,4-syn addition) exerts a dominant influence on aldehyde facial selectivity, by overriding the intrinsic bias imposed by the $\alpha$ and $\beta$ stereocenters in the aldehyde, to give the 1,3-syn product.

Before starting the study described in Scheme 8, we expected that, under conditions that preclude internal chelation, the carbonyl facial bias of anti-disubstituted aldehyde 19 should be highly predictable, since the factors which favors both 1,2- and 1,3-asymmetric induction mutually reinforce nucleophilic addition to give 1,2-syn-1,3-anti diastereomer. ${ }^{16}$ We have observed that this is not the case under the reaction conditions described here. 
Achiral allyltrichlorostannane $\mathbf{4}$ additions to chiral anti- $\alpha, \beta$-disubstituted aldehyde $\mathbf{1 9}$ gave the corresponding 1,2-syn-1,3-anti-product 20 as the major product in good yields, although with only 55:45 diastereoselectivity (Scheme 8). ${ }^{13,15}$

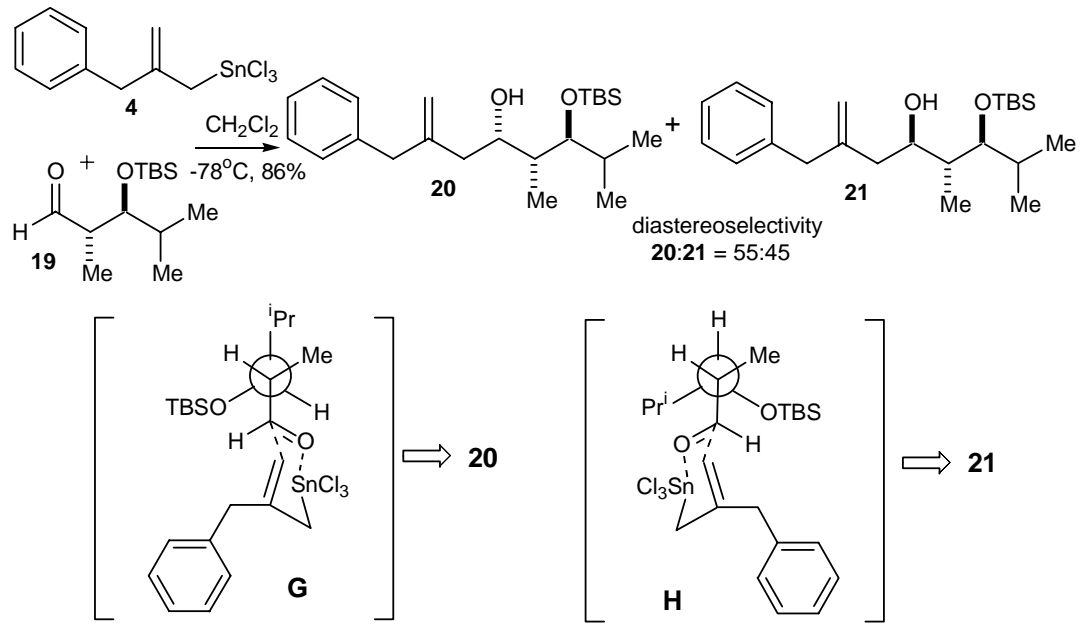

\section{Scheme 8}

This example shows that an anti aldehyde has no facial preference under these conditions, since the Felkin addition to give 1,2-syn isomer competes with the $\beta$-alkoxy stereocenter to give the 1,3-syn isomer. We believe that in this case, the corresponding transition states should be very similar in energy, with conformer $\mathbf{G}$ (which gives the 1,2-syn isomer) being destabilized by the gauche interaction ${ }^{\mathrm{i}} \mathrm{Pr} / \mathrm{Me}$ while conformer $\mathbf{H}$ (which gives the 1,2-anti isomer) being destabilized by the ${ }^{\mathrm{i}} \mathrm{Pr} / \mathrm{C}=\mathrm{O}$ and Me/OTBS gauche interactions (Scheme 8).

Under the same conditions described before allyltrichlorostannane (S)-6 reacted with aldehyde 19 to give 1,2-syn-1,3-anti isomer 22 with 92:8 diastereoselectivity (Scheme 9). ${ }^{13}$

The reaction of allyltrichlorostannane $(R)-\mathbf{6}$ with aldehyde $\mathbf{1 9}$ gave homoallylic alcohol 23 as the major isomer in 88:12 diastereoselectivity (anti-Felkin addition, partially matched case).

The results described in Scheme 9 can be rationalized with dominant acyclic 1,4-asymmetric induction from the chiral allyltrichlorostannane. These are examples of partially matched reactions, with the chiral allyltrichlorostannanes $(R)-6$ and (S)-6 being responsible for the control of the observed diastereoselectivities, through transition states analogous to $\mathbf{I}$ and $\mathbf{J}$, respectively (Scheme 9). Poor levels of diastereoselectivity characterize this reaction with 1,2-anti $\beta$-OTBS aldehydes only when an achiral allyltrichlorostannane is used. This attenuated 1,3-anti selectivity for 1,2-anti aldehydes with the TBS protecting group appears to be general, as similar trends were observed for titanium and boron aldol reaction variants. ${ }^{16}$ One might project that the transition states of these reactions exhibit less charge separation than the aldol processes, and are accordingly less subject to the electrostatic influence of the $\beta$-OTBS function. 


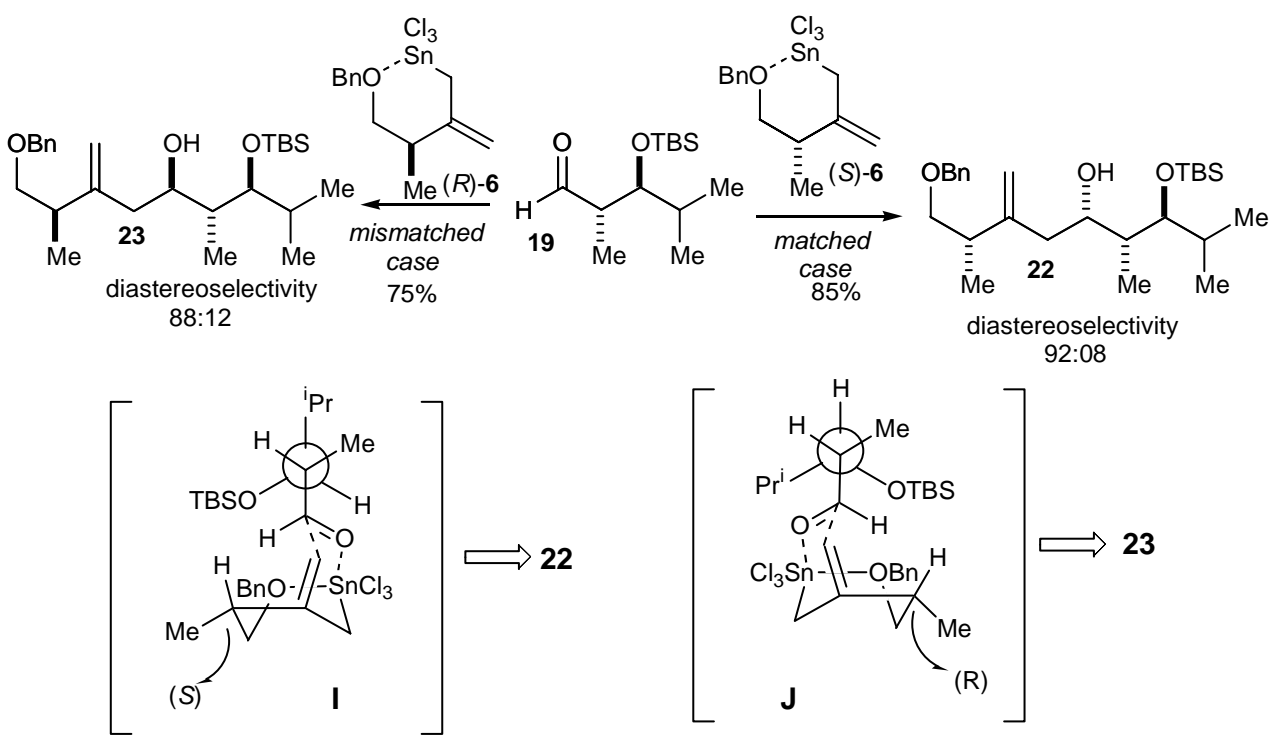

\section{Scheme 9}

The examples presented in this work show that the levels of $\pi$-facial selection are dependent on the absolute stereochemistries of the disubstituted aldehydes as well as of the allyltrichlorostannane.

The results from these experiments suggest that the stereochemical relationships between the $\alpha$ and $\beta$ aldehyde substituents may confer either a reinforcing (matched) or opposing (mismatched) facial bias on the carbonyl moiety. In this complex scenario, the chiral allyltrichlorostannane may adopt either a reinforcing or opposing relationship. One possible reason for this result could be attributed to the involvement of energetically similar chair and twist-boat pericyclic transition states which lead to diastereomeric product formation. Another possibility to consider in these reactions is that nonbonded interactions between the allyltrichlorostannane and aldehyde $\alpha$ substituents may not be significant in pericyclic transition states leading to either Felkin or anti-Felkin addition products. ${ }^{13-17}$

\section{Allyltrichlorostannane additions to $\alpha$-aminoaldehydes}

In recent years there has been a major research effort towards the development of clinically useful inhibitors of aspartyl proteases. ${ }^{18-21}$ This worldwide search has led to various peptide isosteres, wherein the scissile peptide bond is replaced by a hydrolytically more stable isosteric functional group. In this context, the hydroxyl amino acid framework II in Figure 3, where the peptidic linkage of the sequence in structure $\mathbf{I}$ is replaced by a $\mathrm{CH}(\mathrm{OH}) \mathrm{CH}_{2}$ group, constitutes a useful class of aspartyl protease inhibitors. 

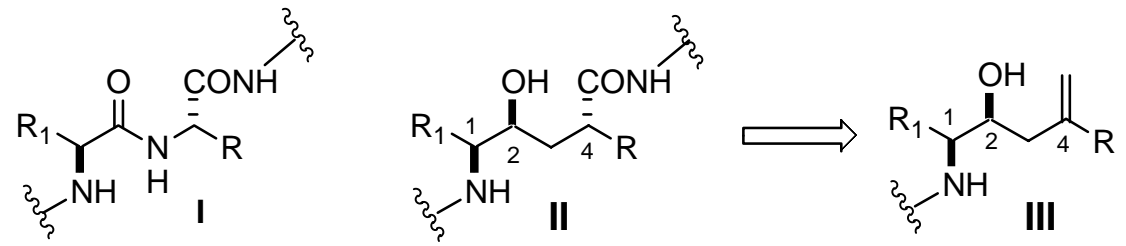

\section{Figure 3}

We were interested to investigate the allyltrichlorostannane additions to chiral aldehydes 24. In order to confirm the facial selectivities of the $(S)$ - $N$-Boc- $\alpha$-aminoaldehydes 24 , we reacted them with allyltrichlorostannane 2 (Scheme 10). ${ }^{22}$
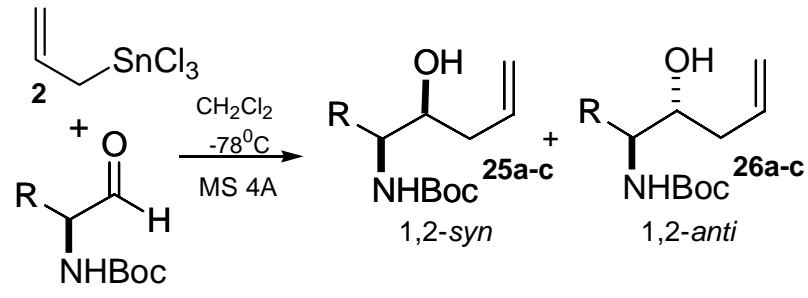

$$
\begin{array}{ll}
\text { (S)-24a, } \mathrm{R}=\mathrm{Me} & \mathrm{R}=\mathrm{Me} 88: 12(85 \%) \\
\text { (S)-24b, R }=\mathrm{Bn} & \mathrm{R}=\mathrm{Bn} 90: 10(86 \%) \\
\text { (S)-24c, } \mathrm{R}={ }^{i} \mathrm{Pr} & \mathrm{R}={ }^{\mathrm{i}} \operatorname{Pr} 90: 10(85 \%)
\end{array}
$$

\section{Scheme 10}

In all cases, the major product results from a chelation controlled reaction that mainly gives the 1,2-syn isomers 25a-c, showing that the $(S)$ - $\alpha$-aminoaldehydes $24 \mathbf{a}-\mathbf{c}$ have a preference for anti-Felkin addition (si face attack). ${ }^{22}$

Under the same conditions, chiral allyltrichlorostannane (S)-6 reacted with (S)- $\alpha$ aminoaldehydes 24 to give a mixture of 1,2-syn 25 and 1,2-anti 26 diastereomers with useful diastereoselectivities, favoring the 1,2-syn-isomer with anti-Felkin addition and aldehyde si face attack (Scheme 11).

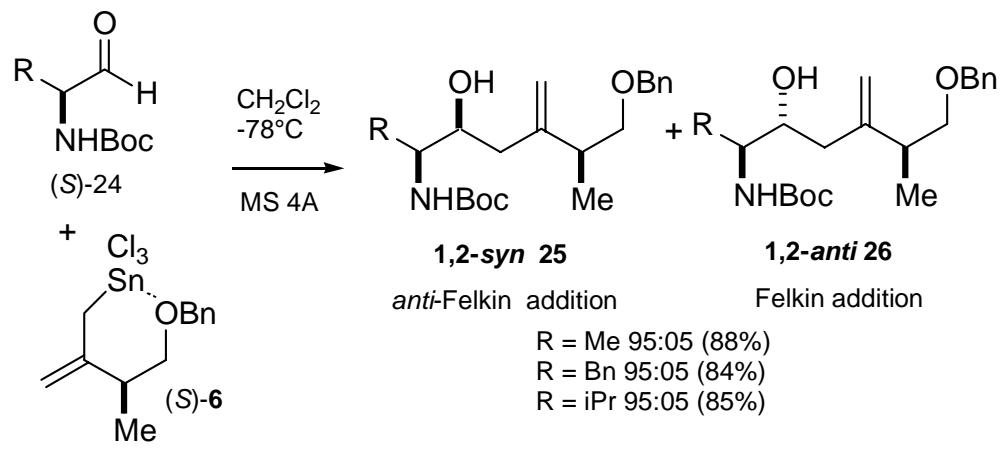

\section{Scheme 11}


As we are aware from previous work that the chiral allyltrichlorostannane $(S)$-6 has a preference for si face approach, this is an example of a matched reaction. It should be noted that this reaction gives a very important subunit with a double bond and a benzyl protected primary alcohol that can be further manipulated.

A synthetic methodology, which allows compounds with programmed variations of substituents to be synthesized, is particularly important in the screening of the pharmacological activity and in a study of structure-activity relationships directed toward the design of the best substituents for positions 1 and 4 in structure III ( $R$ and $R_{1}$ groups in Figure 3 ).

Towards this end we initiated a study towards the synthesis of more complex dipeptide isosteres by reaction of allyltrichlorostannanes with dipeptide aldehydes. ${ }^{23,24}$ The present methodology is useful for the preparation of molecules of type III and consists in the first step in the preparation of molecules of type II (Figure 3). To the best of our knowledge, these were the first examples of successfully allylsilane additions to chiral dipeptide aldehydes.

The results of allyltrichlorostannane additions to dipeptide aldehydes 27a-f are shown in Scheme 12. In all cases, the major product results from a chelation controlled reaction that mainly gives the 1,2-syn isomer, showing that the $(S)$ - $\alpha$-amino dipeptide aldehydes have a preference for anti-Felkin addition (si face attack). Increased steric bulk of the $\mathrm{R}_{2}$ group $\left(\mathrm{R}_{2}={ }^{\mathrm{i}} \mathrm{Pr},{ }^{\mathrm{i}} \mathrm{Bu}\right)$ in the aldehydes gives better diastereoselection. With small $\mathrm{R}_{2}$ groups $\left(\mathrm{R}_{2}=\mathrm{Me}, \mathrm{Bn}, \mathrm{CH}_{2} \mathrm{OTBS}\right)$ the diastereoselectivity is poor, although the reaction occurs in very good yields. It is essential to promote the ligand exchange reaction before addition of the aldehyde in order to get good yields and selectivities.

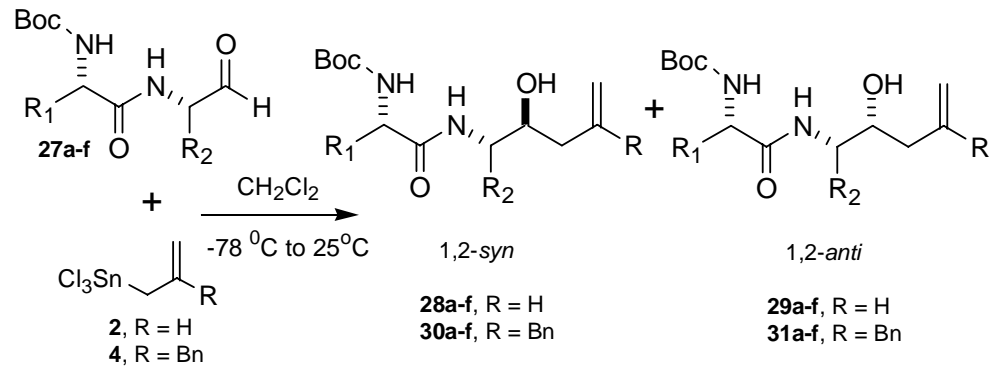
Dipeptide Aldehydes 27
$\mathrm{R}=\mathrm{H}$
$\mathrm{R}=\mathrm{Bn}$

\begin{tabular}{cccccc}
\hline $\mathrm{R}_{1}$ & $\mathrm{R}_{2}$ & $\mathbf{2 8 : 2 9}$ & Yield (\%) & $\mathbf{3 0 : 3 1}$ & Yield (\%) \\
$\mathrm{Bn}$ & $\mathrm{Me}$ & $78: 22$ & 87 & $68: 32$ & 80 \\
$\mathrm{Bn}$ & ${ }^{i} \mathrm{Pr}$ & $95: 05$ & 89 & $95: 05$ & 89 \\
$\mathrm{Bn}$ & ${ }^{i} \mathrm{Bu}$ & $90: 10$ & 83 & $90: 10$ & 83 \\
$\mathrm{Bn}$ & $\mathrm{Bn}$ & $60: 40$ & 79 & $60: 40$ & 70 \\
${ }^{i} \mathrm{Pr}$ & $\mathrm{Bn}$ & $53: 47$ & 74 & $60: 40$ & 75 \\
$\mathrm{Bn}$ & $\mathrm{CH}_{2} \mathrm{OTBS}$ & $66: 34$ & 86 & $60: 40$ & 74 \\
\hline
\end{tabular}




\section{Scheme 12}

Although the remote stereogenic center may influence the stereochemical course of C-C bond formation, we expect such reactions to be dominated by the stereogenic center next to the aldehyde function. We believe that the observed selectivity can be explained by an equilibrium between the intramolecular hydrogen bond conformer $(\mathbf{K})$ and a not bonded conformer $(\mathbf{L})$ (Figure 4). ${ }^{22,23}$ When the form $\mathbf{K}$ predominates (bulkier $\mathrm{R}$ groups), the syn isomer is favored whereas the prevalence of the L-like conformer (smaller $\mathrm{R}$ groups) leads to the anti isomer. The nucleophile selects the less hindered si-face forming a six membered transition state $\mathbf{M}$ where the chiral residue of the aldehyde occupies a pseudo-equatorial position. ${ }^{24-27}$
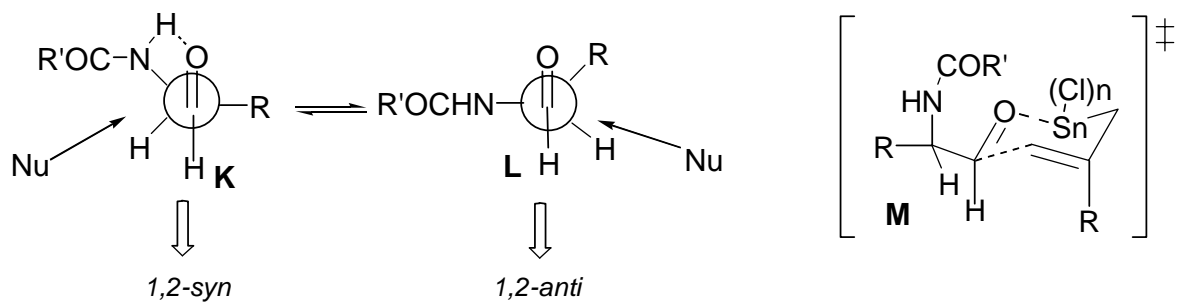

\section{Figure 4}

We have applied this protocol to the synthesis of tripeptide 36 (Scheme 13). Acetonide formation from $\mathbf{2 8 b}$ followed by hydroboration with $\mathrm{BH}_{3}-\mathrm{THF}$ followed by Dess-Martin and Pinnick oxidation gave carboxylic acid 33 in 44\% overall yield. Coupling of 33 with 34 using standard conditions gave 35 that was treated with the complex $\mathrm{BF}_{3}-2 \mathrm{AcOH}$ in $\mathrm{MeOH}$ to give tripeptide 36 in $66 \%$ overall yield.
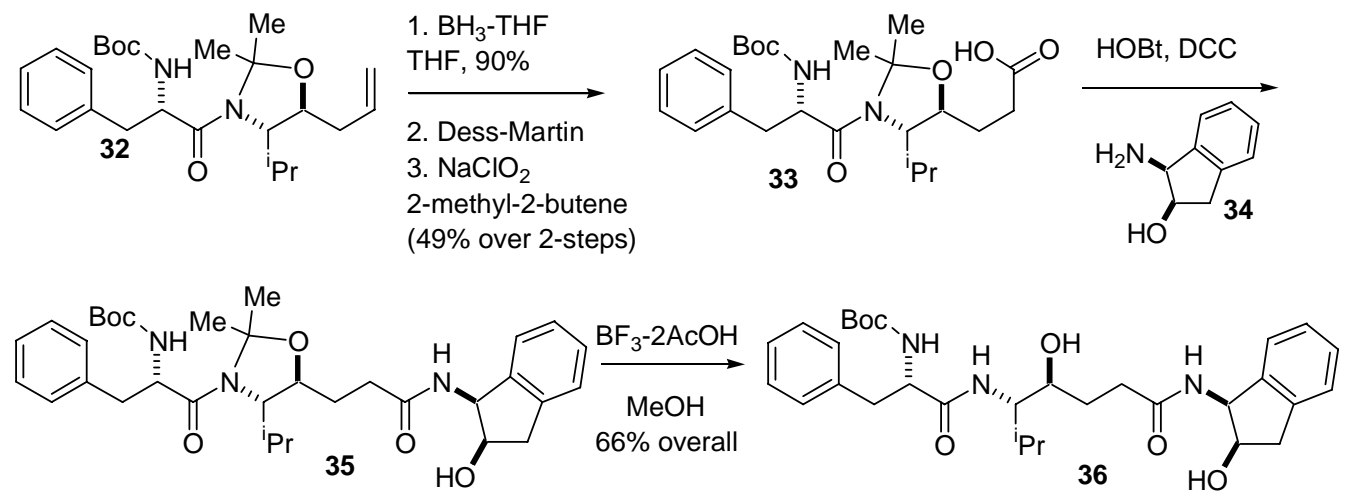

\section{Scheme 13}

Total synthesis of aspartyl protease inhibitors 
Based on our initial results on allyltrichlorostannane additions to $N$-Boc- $\alpha$-aminoaldehydes and attracted by the HIV inhibitory potency of L685,434 (37), L-682,679 (38) as well as by the highly potent inhibition of A $\beta$ PP $\gamma$-secretase activity of L-685,458 (39), we initiated a project directed towards their total synthesis (Figure 5). The approach described here to L685,434 (37), L-682,679 (38), and L-685,458 (39) might also give access to additional derivatives with potential relevance for biological evaluation. ${ }^{28-30}$

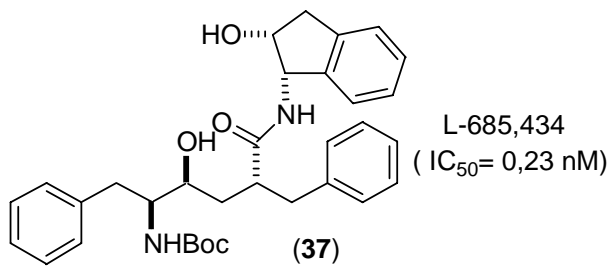

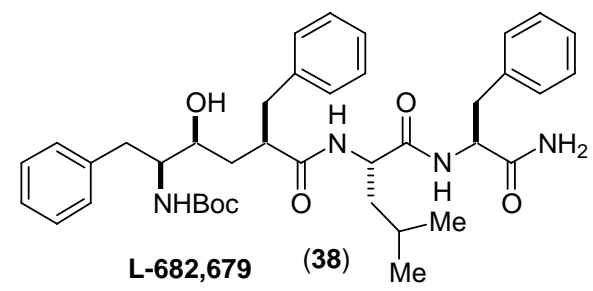

HIV: IC ${ }_{50}>10000 \mathrm{nM}$ $\gamma$-secretase: $\mathrm{IC}_{50}=0,42 \mathrm{nM}$

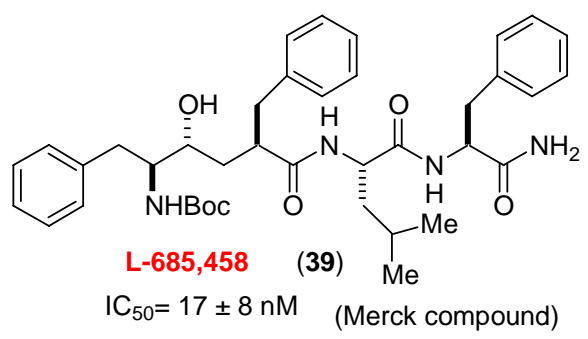

- Originally developed as an HIV protease inhibitor - Poor inhibitor of HIV protease but a potent inhibitor of $\gamma$-secretase

\section{Figure 5}

Addition of the aldehyde 24b to a $\mathrm{CH}_{2} \mathrm{Cl}_{2}$ solution of allyltrichlorostannane 4 at $-78^{\circ} \mathrm{C}$ gave the 1,2-syn aminoalcohol $\mathbf{4 0}$ in 94\% yield and 95:5 diastereoselectivity (Scheme 14). ${ }^{31,32}$

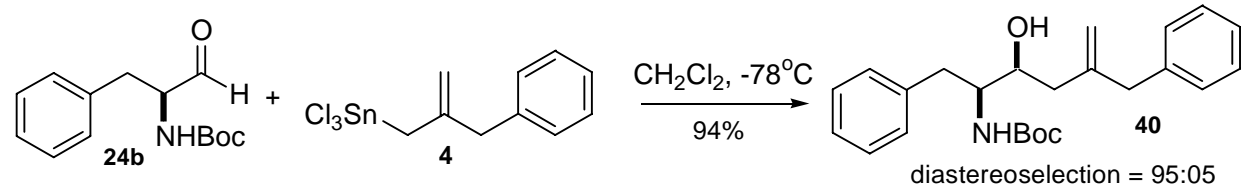

\section{Scheme 14}

Direct hydroboration of the unprotected homoallylic alcohol 40 with $\mathrm{BH}_{3}$.DMS in $\mathrm{THF}$ at $0^{\circ} \mathrm{C}$ gave a mixture of diols 41 and 42, in 93\% yield (Scheme 15).

These diols were not separated but were converted directly to a mixture of lactones $\mathbf{4 3}$ and $\mathbf{4 4}$ (95\% yield) by treatment with TPAP and NMO in the presence of molecular sieves at room temperature. $^{31,32}$ These lactones were readily separated by flash column chromatography. Although these lactones have been prepared earlier by others, the relative stereochemistry for cis-lactone 44 was ascertained by NOESY experiments (observed interaction between $\mathrm{Ha}$ and 
$\mathrm{Hb}$ ). Attempts to obtain more of the desired trans-lactone 43 by a deprotonation and reprotonation sequence of cis-lactone 44 led to a 70:30 mixture of lactones $43: 44$ in 96\% yield (Scheme 15). It is interesting to point out that cis-lactone $\mathbf{4 4}$ is also an important intermediate for the synthesis of other potent HIV-1 protease inhibitors. ${ }^{31,32}$

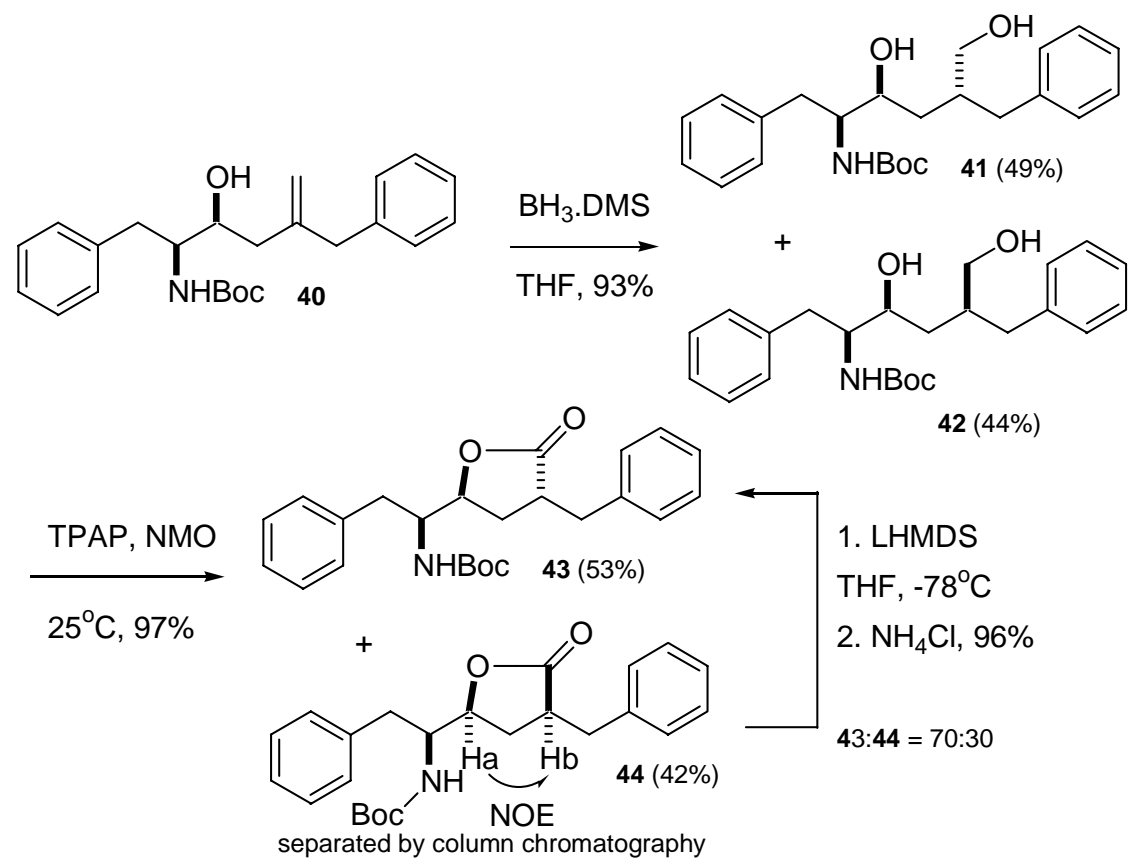

\section{Scheme 15}

Basic hydrolysis of desired trans-lactone 43 ( $\mathrm{LiOH}$, 1,2-dimethoxyethane), silylation (TBSCl, imidazole, DMF, room temperature, 12h) of the resulting carboxylate, and selective desilylation of the acylsiloxy moiety $(\mathrm{MeOH})$ cleanly provided 45 in excellent yield after purification by silica-gel flash chromatography (Scheme 16). 


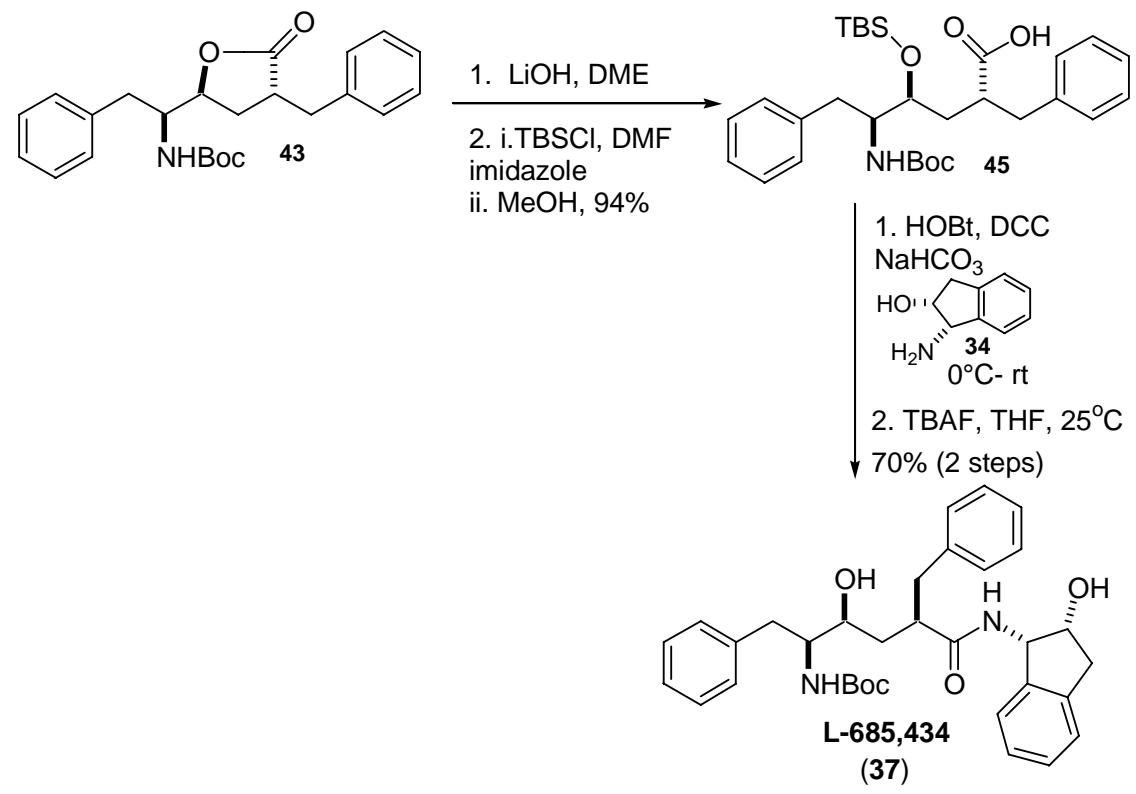

\section{Scheme 16}

Compound L-685,434 (37) was readily prepared from carboxylic acid 45 by a simple peptide coupling reaction with $1(S)$-amino-2(R)-hydroxyindane 34 followed by TBS removal with TBAF in $70 \%$ yield for the 2-step sequence (Scheme 16).

Compound L-682,679 (38) is also prepared from carboxylic acid 45 and dipeptidic amine $\mathrm{NH}_{2}$ Leu-Phe- $\mathrm{NH}_{2}$ by a simple peptide coupling reaction followed by TBS deprotection with TBAF in $86 \%$ overall yield (Scheme 17). ${ }^{31,32}$ 


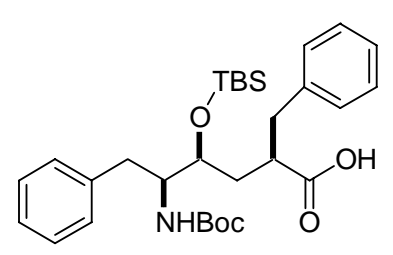

45<smiles>CC(C)C[C@H](NC(=O)[C@H](Cc1ccccc1)CC(O)C(Cc1ccccc1)N[C@H](Cc1ccccc1)C(N)=O)C(=O)N[C@H](Cc1ccccc1)C(N)=O</smiles>

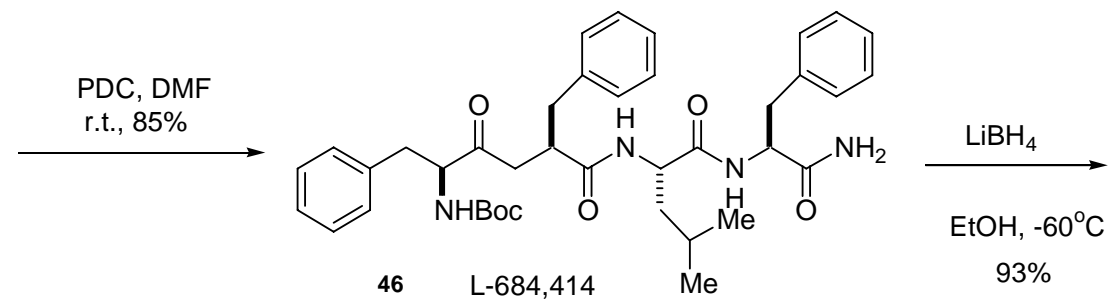

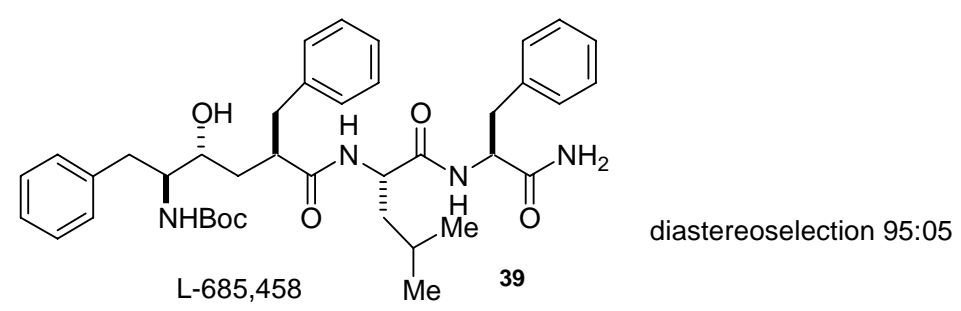

\section{Scheme 17}

Oxidation of the hydroxyl function in 38 with PDC in DMF gave inhibitor L-684,414 (46) in $85 \%$ isolated yield. Selective reduction of L-684,414 (46) with $\mathrm{LiBH}_{4}$ gave $\gamma$-secretase inhibitor L-685,458 (39) in 93\% yield and 95:5 diastereoselection (Scheme 17). ${ }^{31,32}$

\section{Conclusions}

We believe that this chemistry is truly significant in the context of acyclic diastereoselection and will prove to be useful in the synthesis of more complex molecules like polyacetate and polypropionate-derived natural products as well as in the synthesis of a variety of dipeptide isosteres with promising pharmacological activity.

\section{Experimental Section}

General Procedures. All reactions were carried out under an atmosphere of argon or nitrogen in flame-dried glassware with magnetic stirring. Dichloromethane, triethylamine, cyclohexane, and dimethylformamide were distilled from $\mathrm{CaH}_{2}$. Tin tetrachloride was distilled from $\mathrm{P}_{2} \mathrm{O}_{5}$ and stored in a Schlenk flask. Dimethyl sulfoxide was distilled under reduced pressure from calcium 
hydride and stored over molecular sieves. THF, diethyl ether and toluene were distilled from sodium/benzophenone ketyl. Oxalyl chloride, dimethoxypropane, isobutyraldehyde, trimethylsilylmethyl chloride and (c-Hex $)_{2} \mathrm{BCl}$ were distilled immediately prior to use. $\mathrm{MeOH}$ was distilled from $\mathrm{Mg}(\mathrm{OMe})_{2}$. TLC plates were silica gel 60 (GF 5-40- $\mu \mathrm{m}$ ). Visualization was accomplished with either a UV lamp or $\mathrm{I}_{2}$ staining. Chromatography on silica-gel (230-400mesh) was performed using forced-flow of the indicated solvent system (flash chromatography). Visualization was accomplished with UV light and an anisaldehyde, ceric ammonium nitrate stain, a heated phosphomolybdic acid or by $\mathrm{I}_{2}$ staining. ${ }^{1} \mathrm{H}$ NMR spectra were recorded on either a Varian Gemini $300(300 \mathrm{MHz})$ or a Varian Inova $500(500 \mathrm{MHz})$ spectrometer and are reported in ppm using solvent as an internal standard $\left(\mathrm{CDCl}_{3}\right.$ at $7.26 \mathrm{ppm}$ or $\mathrm{C}_{6} \mathrm{D}_{6}$ at $\left.7.15 \mathrm{ppm}\right)$ unless otherwise indicated. Data are reported as $(\mathrm{ap}=$ apparent, $\mathrm{s}=$ singlet, $\mathrm{d}=$ doublet, $\mathrm{t}=$ triplet, $\mathrm{q}=$ quartet, $\mathrm{qt}=$ quintet, $\mathrm{st}=$ sextet, apt $=$ apparent triplet, $\mathrm{m}=$ multiplet, $\mathrm{b}=$ broad, brs $=$ broad singlet, brd = broad doublet, $\mathrm{dq}=$ doublet of quartets, $\mathrm{dt}=$ doublet of triplets, $\mathrm{td}=$ triplet of doublets, apqt $=$ apparent quintet, apdt $=$ apparent doublet of triplets, number of hydrogens, coupling constant(s) in Hz. Proton-decoupled ${ }^{13} \mathrm{C}$ NMR spectra were recorded on either a Varian Gemini $300(75 \mathrm{MHz})$ or Bruker AC 300/P (75 MHz) spectrometers and are recorded in ppm using solvent as an internal standard $\left(\mathrm{CDCl}_{3}\right.$ at $77.0 \mathrm{ppm}$ or $\mathrm{C}_{6} \mathrm{D}_{6}$ at $\left.128 \mathrm{ppm}\right)$ unless otherwise indicated. Infrared spectra were recorded on a Perkin-Elmer 1600 FTIR spectrophotometer. Mass spectra were recorded on a HP-5988-A GC-MS. Optical rotations were measured on a Polamat A polarimeter from Carl Zeiss Jen, using a $1 \mathrm{~mL}$ quartz cell, with mercury or sodium lamps, and are reported as follows: $[\mathrm{a}]^{\mathrm{t}(\mathrm{oC})} \lambda,(\mathrm{c} \mathrm{g} / 100 \mathrm{~mL}$, solvent $)$.

\section{General procedure for the preparation of homoallylic alcohols 11-13, 15, 17, 20-22-23}

To a solution of allylsilane $5(1.5 \mathrm{mmol})$ in $\mathrm{CH}_{2} \mathrm{Cl}_{2}(5 \mathrm{~mL})$ at $0{ }^{\circ} \mathrm{C}$ was added $\mathrm{SnCl}_{4}(1.5 \mathrm{mmol})$. The resulting solution was stirred at $0^{\circ} \mathrm{C}$ for $5 \mathrm{~min}$ and then cooled to $-78{ }^{\circ} \mathrm{C}$ when a solution of the corresponding aldehyde $(1.5 \mathrm{mmol})$ in $\mathrm{CH}_{2} \mathrm{Cl}_{2}(2 \mathrm{~mL})$ was added. This mixture was stirred for $2 \mathrm{~h}$ at $-78{ }^{\circ} \mathrm{C}$ and quenched by the slow addition of a saturated aqueous solution of $\mathrm{NaHCO}_{3}$ $(5 \mathrm{~mL})$ followed by $\mathrm{CH}_{2} \mathrm{Cl}_{2}(10 \mathrm{~mL})$. The layers were separated and the aqueous layer was extracted with $\mathrm{CH}_{2} \mathrm{Cl}_{2}(2 \times 5 \mathrm{~mL})$. The combined organic layer was dried $\left(\mathrm{MgSO}_{4}\right)$, filtered, and concentrated in vacuo. Purification by flash chromatography on silica gel (10\% EtOAc/hexane) gave the corresponding homoallylic alcohols.

(2S,4S)-6-Benzyl-2-[tert-butyl(dimethyl)silyloxy]-6-octen-4-ol (11). $\quad$ TLC: $\quad \mathrm{R} f \quad 0.20 \quad(5 \%$ EtOAc/hexanes); ${ }^{1} \mathrm{H} \mathrm{NMR}\left(\mathrm{CDCl}_{3}, 300 \mathrm{MHz}\right): \delta 0.10(\mathrm{~s}, 3 \mathrm{H}), 0.11(\mathrm{~s}, 3 \mathrm{H}), 0.92(\mathrm{~s}, 9 \mathrm{H}), 1.17(\mathrm{~d}$, $J 6.2 \mathrm{~Hz}$, minor isomer) + $1.20(\mathrm{~d}, 3 \mathrm{H}, J 6.2 \mathrm{~Hz}), 1.45-1.63(\mathrm{~m}, 2 \mathrm{H}), 2.04-2.26(\mathrm{~m}, 2 \mathrm{H}), 3.39(\mathrm{~s}$, $2 \mathrm{H}), 3.86-4.06+4.08-4.26(\mathrm{~m}, 2 \mathrm{H}), 4.88(\mathrm{~s}, 1 \mathrm{H}), 4.94(\mathrm{~s}, 1 \mathrm{H}), 7.16-7.34(\mathrm{~m}, 5 \mathrm{H}) ;{ }^{13} \mathrm{C} \mathrm{NMR}$ $\left(\mathrm{CDCl}_{3}, 75 \mathrm{MHz}\right): \delta$-4.8, -4.6, -4.3, -3.8, 18.0, 18.1, 23.3, 24.5, 25.9, 43.1, 43.2, 44.0, 44.1, 44.6, $45.5,65.9,67.1,68.9,69.6,113.9,114.0,126.0,128.2,128.9,139.2,145.6,145.8$.

(2S,4S)-6-[(S)-2-Benzyloxy-1-methylethyl]-2-[tert-butyl(dimethyl)silyloxy]-6-hepten-4-ol (12). TLC: Rf 0.22 (10\% EtOAc/hexanes); ${ }^{1} \mathrm{H}$ NMR $\left(\mathrm{CDCl}_{3}, 300 \mathrm{MHz}\right): \delta 0.08$ (s, 3H), 0.09 (s, $3 \mathrm{H}), 0.91(\mathrm{~s}, 9 \mathrm{H}), 1.05$ (d, 3H, J $7.0 \mathrm{~Hz}), 1.19$ (d, 3H, J 6.2 Hz), $1.58(\mathrm{~m}, 2 \mathrm{H}), 2.18$ (d, 2H, J 5.5 
Hz), $2.49(\mathrm{~m}, 1 \mathrm{H}), 3.23($ br s, 1H), $3.37(\mathrm{dd}, 1 \mathrm{H}, J 9.2$ and $6.4 \mathrm{~Hz}), 3.49$ (dd, 1H, J 9.2 and 7.7 $\mathrm{Hz}), 4.08(\mathrm{~m}, 1 \mathrm{H}), 4.15(\mathrm{~m}, 1 \mathrm{H}), 4.52(\mathrm{~s}, 2 \mathrm{H}), 4.93(\mathrm{~s}, 2 \mathrm{H}), 7.25-7.40(\mathrm{~m}, 5 \mathrm{H})$; ${ }^{13} \mathrm{C} \mathrm{NMR}$ $\left(\mathrm{CDCl}_{3}, 75 \mathrm{MHz}\right): \delta-4.8,-4.3,17.6,18.1,23.8,26.0,39.2,44.4,45.3,65.9,66.6,73.1,74.7$, $111.7,127.5,127.6,128.2,138.1,149.1$.

(2S,4R)-6-[(R)-2-Benzyloxy-1-methylethyl]-2-[tert-butyl(dimethyl)silyloxy]-6-hepten-4-ol (13). TLC: Rf 0.24 (10\% EtOAc/hexanes); ${ }^{1} \mathrm{H}$ NMR $\left(\mathrm{CDCl}_{3}, 300 \mathrm{MHz}\right): \delta 0.09+0.10+0.11+$ $0.12(\mathrm{~s}, 6 \mathrm{H}), 0.90(\mathrm{~s})+0.91(\mathrm{~s}, 9 \mathrm{H}), 1.07(\mathrm{~d}, J 7.0 \mathrm{~Hz})+1.10(\mathrm{~d}, 3 \mathrm{H}, J 7.0 \mathrm{~Hz}), 1.18(\mathrm{~d}, J 5.9 \mathrm{~Hz})$ $+1.20(\mathrm{~d}, 3 \mathrm{H}, J 6.2 \mathrm{~Hz}), 1.50-1.65(\mathrm{~m}, 2 \mathrm{H}), 2.16-2.24(\mathrm{~m}, 2 \mathrm{H}), 2.49(\mathrm{~m}, 1 \mathrm{H}), 3.30-3.45(\mathrm{~m}, 2 \mathrm{H})$, $3.51(\mathrm{~m}, 1 \mathrm{H}), 3.90-4.22(\mathrm{~m}, 2 \mathrm{H}), 4.52(\mathrm{~s}, 2 \mathrm{H}), 4.93(\mathrm{~s}, 2 \mathrm{H}), 7.25-7.40(\mathrm{~m}, 5 \mathrm{H}) ;{ }^{13} \mathrm{C} \mathrm{NMR}\left(\mathrm{CDCl}_{3}\right.$, $75 \mathrm{MHz}): \delta-4.6,-3.9,17.5,18.1,23.5,24.3,25.9,29.8,39.2,43.9,44.2,45.1,45.7,66.5,66.8$, $68.3,68.8,71.1,73.0,74.6,74.7,111.7,111.8,125.9,126.3,127.5,128.7,130.2,138.2,148.8$, 149.0 .

(4R,5S,6S)-2-Benzyl-6-O-tert-butyldimethylsilyloxy-5,7-dimethyl-1-octen-4-ol (15). TLC Rf: 0.48 (10\% EtOAc/hexanes); $\alpha]^{20}{ }_{\mathrm{D}}:+5.0$ (c 2.18, EtOAc); ${ }^{1} \mathrm{H} \mathrm{RMN}\left(\mathrm{CDCl}_{3}, 300 \mathrm{MHz}\right): \delta 0.13$ $(\mathrm{s}, 6 \mathrm{H}), 0.92(\mathrm{~d}, 3 \mathrm{H}, J 7.0 \mathrm{~Hz}), 0.97$ (br s, 15H, J 5.5 Hz), $1.69(\mathrm{~m}, 1 \mathrm{H}), 1.89$ (m, 1H), 1.96 (br s, 1H), 2.22 (d, 2H, J 6.6 Hz), 3.45 (br s, 2H), 3.58 (t, 1H, J $3.7 \mathrm{~Hz}$ ), 3.85 (br s, 1H), 4.96 (br s, 1H), 5.02 (br s, $1 \mathrm{H}), 7.25-7.39(\mathrm{~m}, 5 \mathrm{H}) ;{ }^{13} \mathrm{C} \mathrm{NMR}\left(\mathrm{CDCl}_{3}, 75 \mathrm{MHz}\right): \delta$-3.6, -3.1, 9.6, 18.6, 18.8, 19.6, 26.5, 33.1, 40.5, 42.2, 43.4, 71.9, 79.8, 114.8, 126.7, 128.8, 129.4, 139.7, 146.6; IR (film): v 3571, 3480, 3063, 3027, 3480, 2959, 2922, 2858, 1645, 1602, 1496, 1471, 1259, 1091, 1027 , $826 \mathrm{~cm}^{-1}$.

(2S,3R,4R)-6-[(1R)-2-Benzyloxy-1-methylethyl]-3-methyl-6-hepten-2,4-diol (17). TLC Rf: 0.40 (10\% EtOAc/hexanes); $[\alpha]_{\mathrm{D}}:+20.7$ (c 0.42, $\left.\mathrm{CHCl}_{3}\right) ;{ }^{1} \mathrm{H}$ NMR $\left(\mathrm{CDCl}_{3}, 300 \mathrm{MHz}\right): \delta 0.07$ $(\mathrm{s}, 3 \mathrm{H}), 0.08$ (s, 3H), 0.87 (d, $3 \mathrm{H}, J 6.8 \mathrm{~Hz}), 0.91$ (d, 3H, J $6.3 \mathrm{~Hz}), 0.92$ (s, 9H), 0.94 (d, 3H, J $6.8 \mathrm{~Hz}), 1.04(\mathrm{~d}, 3 \mathrm{H}, J 6.8 \mathrm{~Hz}), 1.67(\mathrm{~m}, 1 \mathrm{H}), 1.84(\mathrm{~m}, 1 \mathrm{H}), 2.15(\mathrm{dd}, 1 \mathrm{H}, J 9.4$ and $14.0 \mathrm{~Hz})$, $2.23(\mathrm{dd}, 1 \mathrm{H}, J 3.7$ and $13.9 \mathrm{~Hz}), 2.47(\mathrm{~m}, 1 \mathrm{H}), 3.37(\mathrm{dd}, 1 \mathrm{H}, J 6.1$ and $9.0 \mathrm{~Hz}), 3.48(\mathrm{dd}, 1 \mathrm{H}, J$ 8.1 and $9.0 \mathrm{~Hz}), 3.55(\mathrm{t}, 1 \mathrm{H}, J 4.1 \mathrm{~Hz}), 3.81(\mathrm{~m}, 1 \mathrm{H}), 4.50(\mathrm{~s}, 2 \mathrm{H}), 4.94(\mathrm{~s}, 1 \mathrm{H}), 4.95(\mathrm{~s}, 1 \mathrm{H})$, 7.26-7.36 (m, 5H); ${ }^{13} \mathrm{C} \mathrm{NMR}\left(\mathrm{CDCl}_{3}, 75 \mathrm{MHz}\right): \delta-3.9,-3.6,9.8,17.6,18.1,18.4,19.5,26.1$, 32.6, 39.0, 40.6, 41.7, 71.0, 73.1, 74.6, 78.9, 111.9, 127.6, 127.7, 128.3, 138.1, 149.4; IR (film): v 3471, 3065, 3025, 2963, 2922, 2854, 1641, 1464, 1258, 1105, 1047, 841, 773, 738, $698 \mathrm{~cm}^{-1}$; HRMS Calcd. for $\mathrm{C}_{26} \mathrm{H}_{46} \mathrm{O}_{3} \mathrm{Si}: 434,3216$; found: 373.2499; MS (70 eV): m/z: $373(3 \%), 305$ (2\%), 269 (5\%), 245 (9\%), 223 (4\%), 187 (77\%), 147 (43\%), 115 (7\%), 91 (100\%).

(3S,4R,5S)-7-[(S)-2-Benzyloxy-1-methylethyl]-3-[tert-butyl(dimethyl)silyloxy]-2,4-dimethyl7-octen-5-ol (22). TLC: Rf 0.20 (5\% EtOAc/hexanes); ${ }^{1} \mathrm{H} \mathrm{NMR}\left(\mathrm{CDCl}_{3}, 300 \mathrm{MHz}\right): \delta 0.11$ (s, $3 \mathrm{H}), 0.13$ (s, 3H), 0.91 (d, 3H, J $7.0 \mathrm{~Hz}), 0.93$ (d, 3H, J $6.6 \mathrm{~Hz}), 0.94$ (s, 9H), 0.99 (d, 3H, J 7.0 $\mathrm{Hz}), 1.10(\mathrm{~d}, 3 \mathrm{H}, J 7.0 \mathrm{~Hz}), 1.70(\mathrm{ddd}, 1 \mathrm{H}, J$ 7.0, 3.7 and $1.8 \mathrm{~Hz}), 1.92(\mathrm{~m}, 1 \mathrm{H}), 2.13(\mathrm{dd}, 1 \mathrm{H}, J$ 14.0 and $6.0 \mathrm{~Hz}), 2.29(\mathrm{dd}, 1 \mathrm{H}, J 14.0$ and $7.7 \mathrm{~Hz}$ ), $2.49(\mathrm{~m}, 1 \mathrm{H}), 3.30(\mathrm{~s}, 1 \mathrm{H}), 3.33(\mathrm{~m}, 1 \mathrm{H})$, $3.48(\mathrm{dd}, 1 \mathrm{H}, J 6.2$ and $3.7 \mathrm{~Hz}), 3.53(\mathrm{dd}, 1 \mathrm{H}, J 9.2$ and $5.9 \mathrm{~Hz}),$,4.25 (ddd, 1H, J 7.7, 6.2 and $1.8 \mathrm{~Hz}), 4.52(\mathrm{~s}, 2 \mathrm{H}), 4.91(\mathrm{~s}, 1 \mathrm{H}), 4.95(\mathrm{~s}, 1 \mathrm{H}), 7.20-7.40(\mathrm{~m}, 5 \mathrm{H}) ;{ }^{13} \mathrm{C} \mathrm{NMR}\left(\mathrm{CDCl}_{3}, 75 \mathrm{MHz}\right)$ : $\delta$-3.6, -3.5, 11.8, 17.4, 18.5, 19.1, 19.9, 26.3, 32.2, 38.0, 39.3, 41.0, 68.7, 73.0, 74.7, 83.1, 111.3, $127.3,127.5,128.2,138.3,148.9$. 
(3S,4R,5R)-7-[(R)-2-Benzyloxy-1-methylethyl]-3-[tert-butyl(dimethyl)silyloxy]-2,4-dimethyl7-octen-5-ol (23). TLC: Rf 0.24 (5\% EtOAc/hexanes); ${ }^{1} \mathrm{H} \mathrm{NMR}\left(\mathrm{CDCl}_{3}, 300 \mathrm{MHz}\right.$ ): $\delta 0.09$ (s, $3 \mathrm{H}), 0.10$ (s, 3H), 0.91 (d, 3H, J 7.0 Hz), 0.92 (d, 3H, J 6.6 Hz), 0.93 (d, 3H, J 7.0 Hz), 0.94 (s, 9H), 1.08 (d, 3H, J 7.0 Hz), 1.75-1.90 (m, 2H), $2.00(\mathrm{dd}, 1 \mathrm{H}, J 14.3$ and $10.3 \mathrm{~Hz}), 2.42(\mathrm{br} \mathrm{d}, 1 \mathrm{H}$, $J 14.3 \mathrm{~Hz}$ ), 2.50 (m, 1H), 2.55 (brs, $1 \mathrm{H}), 3.40$ (dd, $1 \mathrm{H}, J 9.0$ and $6.6 \mathrm{~Hz}), 3.53$ (dd, $1 \mathrm{H}, J 9.0$ and $7.5 \mathrm{~Hz}$ ), 3.60 (ap t, 1H, J 4.6 Hz), 3.76 (ddd, 1H, J 10.3, 8.4 and $2.6 \mathrm{~Hz}$ ), 4.52 (s, 2H), 4.94 (s, $1 \mathrm{H}), 4.98(\mathrm{~s}, 1 \mathrm{H}), 7.25-7.40(\mathrm{~m}, 5 \mathrm{H}) ;{ }^{13} \mathrm{C} \mathrm{NMR}\left(\mathrm{CDCl}_{3}, 75 \mathrm{MHz}\right): \delta$-4.1, -3.7, 14.1, 17.9, 18.4, 18.5, 20.6, 26.2, 32.1, 39.0, 41.4, 43.2, 70.6, 73.0, 74.7, 79.8, 111.4, 127.4, 127.5, 128.2, 138.1, 149.4 .

\section{General procedure for the preparation of homoallylic alcohols 28a-c-30b-c}

To a solution of allylsilane $(1.5 \mathrm{mmol})$ in $\mathrm{CH}_{2} \mathrm{Cl}_{2}(5 \mathrm{~mL})$ at r.t. was added $\mathrm{SnCl}_{4}(1.4 \mathrm{mmol})$. The resulting solution was stirred at $\mathrm{rt}$ for $2 \mathrm{~h}$ and then cooled to $-78{ }^{\circ} \mathrm{C}$ when a solution of the corresponding aldehyde $(1.4 \mathrm{mmol})$ in $\mathrm{CH}_{2} \mathrm{Cl}_{2}(2 \mathrm{~mL})$ was added. This mixture was stirred for 2 $\mathrm{h}$ at $-78{ }^{\circ} \mathrm{C}$ and quenched by the slow addition of a saturated aqueous solution of $\mathrm{NaHCO}_{3}(5$ $\mathrm{mL})$ followed by $\mathrm{CH}_{2} \mathrm{Cl}_{2}(5 \mathrm{~mL})$. The layers were separated and the aqueous layer was extracted with $\mathrm{CH}_{2} \mathrm{Cl}_{2}(2 \times 5 \mathrm{~mL})$. The combined organic layer was dried $\left(\mathrm{MgSO}_{4}\right)$, filtered, and concentrated in vacuo. Purification by flash chromatography on silica gel (20-30\% EtOAc/hexane) gave the corresponding homoallylic alcohols.

(4S,5S)-5-[ $N$-(tert-Butoxycarbonyl-(S)-phenylalanyl)amino]-1-hexenyl-4-ol (28a). TLC: R $f$ 0.21 (35\% EtOAc/hexane); mp 100.3-101.9 ${ }^{\circ} \mathrm{C} ;[\alpha]^{20}$ D: -17.8 (c 0.5, $\left.\mathrm{CHCl}_{3}\right) ;{ }^{1} \mathrm{H}$ NMR $\left(\mathrm{CDCl}_{3}\right.$, $300 \mathrm{MHz}): \delta 0.96$ (d, J $6.9 \mathrm{~Hz}$, minor isomer) and 1.06 (d, 3H, J $6.9 \mathrm{~Hz}), 1.39$ (s, 9H), $1.84(\mathrm{~m}$, $1 \mathrm{H}$, minor isomer), $1.96(\mathrm{~m}, 2 \mathrm{H}), 2.52(\mathrm{br} \mathrm{s}, 1 \mathrm{H}), 2.97(\mathrm{~d}, 2 \mathrm{H}, J 6.9 \mathrm{~Hz}), 3.41(\mathrm{~m}, 1 \mathrm{H}), 3.84(\mathrm{~m}$, $1 \mathrm{H}), 4.26(\mathrm{~m}, 1 \mathrm{H}), 5.02(\mathrm{~m}, 2 \mathrm{H}), 5.18(\mathrm{~m}, 1 \mathrm{H}), 5.60(\mathrm{~m}, 1 \mathrm{H}), 6.22(\mathrm{~m}$, minor isomer) and 6.29 (m, $1 \mathrm{H}), 7.13-7.24(\mathrm{~m}, 5 \mathrm{H}) ;{ }^{13} \mathrm{C} \mathrm{NMR}\left(\mathrm{CDCl}_{3}, 75 \mathrm{MHz}\right): \delta 13.5$ (minor isomer), 17.8, 28.2, 38.4 (minor isomer), 38.5, 48.6, 49.0 (minor isomer), 56.0, 72.5 (minor isomer), 72.9, 80.1, 117.6 (minor isomer), 117.9, 126.8, 128.5, 129.3, 134.4 (minor isomer), 136.6, 155.4, 170.7, 171.1; IR (KBr): v 3351, 3072, 2980, 1682, 1641, 1549, 1520, 1457, 1369, 1293, 1247, 1165, 987, 755, $703 \mathrm{~cm}^{-1}$; Elemental analysis calcd. for $\mathrm{C}_{20} \mathrm{H}_{30} \mathrm{~N}_{2} \mathrm{O}_{4}$ : C 66.27, $\mathrm{H} \mathrm{8.34,} \mathrm{N} \mathrm{7.73,} \mathrm{found:} \mathrm{C} 65.60 ; \mathrm{H}$ 8.17, N 7.74; HRMS calcd. for $\mathrm{C}_{20} \mathrm{H}_{30} \mathrm{~N}_{2} \mathrm{O}_{4}$ : 362.2206; found: 362.2206 .

(4S,5S)-5-[ $N$-(tert-Butoxycarbonyl-(S)-phenylalanyl)amino]-6-methyl-1-heptenyl-4-ol (28b). TLC: Rf 0.22 (35\% EtOAc/hexane); mp148.6-150.8 ${ }^{\circ} \mathrm{C}$; $[\alpha]^{20}{ }_{\mathrm{D}}$ : $-40,0\left(\mathrm{c} 1.0, \mathrm{CH}_{2} \mathrm{Cl}_{2}\right) ;{ }^{1} \mathrm{H} \mathrm{NMR}$ $\left(\mathrm{CDCl}_{3}, 300 \mathrm{MHz}\right): \delta 0.84(\mathrm{~d}, 3 \mathrm{H}, J 6.9 \mathrm{~Hz}), 0.93(\mathrm{~d}, 3 \mathrm{H}, J 6.6 \mathrm{~Hz}), 1.41(\mathrm{~s}, 9 \mathrm{H}), 1.83(\mathrm{~m}, 2 \mathrm{H})$, $1.93(\mathrm{~m}, 1 \mathrm{H}), 3.08(\mathrm{~m}, 2 \mathrm{H}), 3.46($ ap t, $1 \mathrm{H}), 3.76(\mathrm{~m}, 1 \mathrm{H}), 4.35$ (ap q, 1H, J $7.3 \mathrm{~Hz}), 5.10(\mathrm{~m}$, $2 \mathrm{H}), 5.18$ (br d, $1 \mathrm{H}, J$ 8,8 Hz), $5.75(\mathrm{~m}, 1 \mathrm{H}), 6.32$ (br d, $J$ 9,5 Hz), 7.18-7.31 (m, 5H); ${ }^{13} \mathrm{C} \mathrm{NMR}$ $\left(\mathrm{CDCl}_{3}, 75 \mathrm{MHz}\right): \delta 19.319 .7,28.2,30.0,37.9,39.2,56.3,58.1,69.4,80.2,118.2,126.9,128.6$, 129.3, 134.0, 136.6, 155.0, 171.6; IR (KBr): v 3345, 3078, 2963, 2933, 1682, 1635, 1549, 1514, 1422, 1369, 1299, 1165, 1038, $703 \mathrm{~cm}^{-1}$; HRMS calcd. 390.2519; found:390.2512.

(4S,5S) 5-[N-(tert-Butoxycarbonyl-(S) -phenylalanyl) amino]7methyl1octenyl4-ol (28c). TLC: Rf 0.23 
(35\% EtOAc/hexane); mp 143.8-145.2 ${ }^{\circ} \mathrm{C} ;[\alpha]^{20}{ }_{\mathrm{D}}:-34.0$ (c 1.0, EtOH); ${ }^{1} \mathrm{H} \mathrm{NMR}\left(\mathrm{CDCl}_{3}, 300 \mathrm{MHz}\right): \delta$ 0.87 (d, 3H, J 6.6 Hz), 0.90 (d, 3H, J 6.6 Hz), 1.37 (m, 2H), 1.42 (s, 9H), 1.87 (m, 1H), 2.07 (br s, 2H), 3.09 (br d, 2H, J 6.2 Hz), 3.53 (m, 1H), 3.92 (m, 1H), 4.32 (ap q, 1H, J 7.3 Hz), 5.02 (m, 2H), 5.14 (br s, 1H), $5.77(\mathrm{~m}, 1 \mathrm{H}), 6.06(\mathrm{~d}, 1 \mathrm{H}, J 9.5 \mathrm{~Hz}), 7.18-7.33(\mathrm{~m}, 5 \mathrm{H}) ;{ }^{13} \mathrm{C} \mathrm{NMR}\left(\mathrm{CDCl}_{3}, 75 \mathrm{MHz}\right): \delta 22.0,23.2,24.5$, 28.2, 37.7, 38.8, 41.5, 50.8, 56.2, 72.2, 80.3, 118.2, 126.9, 128.7, 129.3, 134.5, 136.6, 155.4, 171.1; IR (KBr): v 3438, 3351, 3078, 2951, 1775, 1687, 1641, 1555, 1520, 1363, 1293, 1241, 1178, 1120, $900,870,703 \mathrm{~cm}^{-1}$; Elemental analysis calcd. for $\mathrm{C}_{23} \mathrm{H}_{36} \mathrm{~N}_{2} \mathrm{O}_{4}$ : C 68.29, H 8.97, N 6.92; found: C 68.47, H 8.97, N 6.92; HRMS calcd. for $\mathrm{C}_{23} \mathrm{H}_{36} \mathrm{~N}_{2} \mathrm{O}_{4}$ : 404.2675; found: 404.2601.

(4S,5S)-5-[N-(tert-Butoxycarbonyl-(S)-phenylalanyl)amino]-6-methyl-2-benzyl-1-heptenyl-

4-ol (30b). TLC: $\mathrm{R} f 0.23$ (35\% EtOAc/hexane); mp 132.5-134.3 ${ }^{\circ} \mathrm{C}$; $[\alpha]^{20}{ }_{\mathrm{D}}:-26.3$ (c 0.76 , $\left.\mathrm{CH}_{2} \mathrm{Cl}_{2}\right) ;{ }^{1} \mathrm{H} \mathrm{NMR}\left(\mathrm{CDCl}_{3}, 300 \mathrm{MHz}\right): \delta 0.81(\mathrm{~d}, 3 \mathrm{H}, J 6.6 \mathrm{~Hz}), 0.87(\mathrm{~d}, 3 \mathrm{H}, J 6.6 \mathrm{~Hz}), 1.40(\mathrm{~s}$, 9H), $1.76(\mathrm{~m}, 2 \mathrm{H}), 1.87(\mathrm{~m}, 2 \mathrm{H}), 3.05(\mathrm{~m}, 2 \mathrm{H}), 3.31$ (br d, 2H, J $3.7 \mathrm{~Hz}), 3.41$ (ap t, $1 \mathrm{H}, J 8.8$ $\mathrm{Hz}$ ), 3.74 (br d, 1H, J 7.7 Hz), 4.33 (ap q, 1H, J 7.3 Hz), 4.8 (br s, 1H), 4.87 (br s, 1H), 5.00 (br d, $1 \mathrm{H}, J 8.1 \mathrm{~Hz}), 6.20$ (br d, $1 \mathrm{H}, J 9.5 \mathrm{~Hz}), 7.24(\mathrm{~m}, 10 \mathrm{H}) ;{ }^{13} \mathrm{C} \mathrm{NMR}\left(\mathrm{CDCl}_{3}, 75 \mathrm{MHz}\right): \delta 19.3$, 19.6, 28.2, 30.3, 37.9, 41.2, 42.8, 56.3, 58.2, 67.2, 80.2, 115.2, 126.3, 126.9, 128.4, 128.6, 128.9, 129.3, 136.6, 138.9, 145.2, 155.4, 171.2; IR (KBr): v 3351, 3084, 3031, 2974, 2933, 2869, 1682, 1641, 1549, 1520, 1450, 1363, 1293, 1241, 1165, 1044, 870, 755, $703 \mathrm{~cm}^{-1}$; Elemental analysis calcd. for $\mathrm{C}_{29} \mathrm{H}_{40} \mathrm{~N}_{2} \mathrm{O}_{4}$ : C 72.47, $\mathrm{H} 8.39$, N 5.83; found: C 71.37, H 8.42, N 5,95; HRMS calcd. for $\mathrm{C}_{29} \mathrm{H}_{40} \mathrm{~N}_{2} \mathrm{O}_{4}$ : 480.2988; found: 480.2912 .

(4S,5S)-5-[N-(tert-butoxycarbonyl-(S)-phenylalanyl)amino]-7-methyl-2-benzyl-1-octenyl-4-

ol (30c). TLC: Rf 0.25 (35\% EtOAc/hexane); mp 127.8-131.5 ${ }^{\circ} \mathrm{C} ;[\alpha]^{20}{ }_{\mathrm{D}}:-15.7$ (c 0.6, $\left.\mathrm{CHCl}_{3}\right)$; ${ }^{1} \mathrm{H} \mathrm{NMR}\left(\mathrm{CDCl}_{3}, 300 \mathrm{MHz}\right): \delta 0.85(\mathrm{~d}, 3 \mathrm{H}, J 6.2 \mathrm{~Hz}), 0.88(\mathrm{~d}, 3 \mathrm{H}, J 6.2 \mathrm{~Hz}), 1.42(\mathrm{~s}, 9 \mathrm{H}), 1.80$ $(\mathrm{m}, 1 \mathrm{H}), 1.99(\mathrm{~m}, 2 \mathrm{H}), 3.03$ (d, 2H, J $7.3 \mathrm{~Hz}$ ), 3.30 (ap q, 2H, J 8.2 Hz), 3.55 (br d, 1H, J 8.1 Hz), 3.85 (m, 1H), 4.32 (ap q, 1H, J 6.6 Hz), 4.83 (br s, 1H), 4.85 (br s, 1H), 4.98 (br d, 1H, J 7.3 $\mathrm{Hz}$ ), 6.0 (br d, $1 \mathrm{H}, J 9.1 \mathrm{~Hz}), 7.16-7,30(\mathrm{~m}, 10 \mathrm{H}) ;{ }^{13} \mathrm{C} \mathrm{NMR}\left(\mathrm{CDCl}_{3}, 75 \mathrm{MHz}\right): \delta 22.1,23.1$, 24.6, 28.2, 38.0, 40.7, 41.8, 42.7, 50.9, 56.1, 70.1, 80.2, 115.0, 126.3, 126.9, 128.4, 128.6, 128.9, 129.3, 136.6, 138.9, 145.3, 155.3, 170.9; IR (KBr): v 3348, 3062, 3022, 2974, 2918, 1655, 1500, 1457, 1374, 1252, 1164, 1047, 740, $700 \mathrm{~cm}^{-1}$; Elemental analysis calcd. for $\mathrm{C}_{30} \mathrm{H}_{42} \mathrm{~N}_{2} \mathrm{O}_{4}: \mathrm{C}$ 72.84, H 8.56, N 5.66; found: C 72.69, H 8.40, N 5.58; HRMS calcd. for $\mathrm{C}_{30} \mathrm{H}_{42} \mathrm{~N}_{2} \mathrm{O}_{4}$ : 494.3144; found: 494.3138 .

\section{Acknowledgements}

We are grateful to FAEP-UNICAMP, FAPESP and CNPq (Brazil) for financial support. We also thank Prof. Carol H. Collins, from IQ-UNICAMP, for helpful suggestions about English grammar and style. 


\section{References}

1. (a) Fleming, I.; Barbero, A.; Walter, D. Chem. Rev. 1997, 97, 2063. (b) Nishigaichi, Y.; Takuwa, A.; Naruta, Y.; Maruyama, K. Tetrahedron 1993, 49, 7395.

2. (a) Panek, J. S.; Xu, F.; Rondon, A. C. J. Am. Chem. Soc. 1998, 120, 4113. (b) Zhu, B.; Panek, J. S. Eur. J. Org. Chem. 2001, 9, 1701. (c) Huang, H. B.; Spande, T. F.; Panek, J. S. J. Am. Chem. Soc. 2003, 125, 626. (d) Keck, G. E.; Abbott, D. E. Tetrahedron Lett. 1984, 25, 1883.

3. (a) Trost, B. M.; Urabe, H. J. Org. Chem. 1990, 55, 3982. (b) Nishigaishi, Y.; Takuwa, A.; Jodai, A. Tetrahedron Lett. 1991, 32, 2383.

4. (a) Almendros, P.; Gruttadauria, M.; Helliwell, M.; Thomas, E. J. J. Chem. Soc. Perkin Trans. I 1997, 2549. (b) Deka, D. C.; Helliwell, M.; Thomas, E. J. Tetrahedron 2001, 57, 10017. (c) Martin, N.; Thomas, E. J. Tetrahedron Lett. 2001, 42, 8373. (d) Kumar, P.; Thomas, E. J.; Tray, D. R. J. Braz. Chem. Soc. 2001, 12, 623.

5. (a) Evans, D. A.; Coleman, P. J.; Dias, L. C. Angew Chem. Int. Ed. Engl. 1997, 36, 2738. (b) Evans, D. A.; Trotter, B. W.; Cote, B.; Coleman, P. J.; Dias, L. C.; Tyler, A. N. Angew Chem., Int. Ed. 1997, 36, 2744.

6. Dias, L. C.; Meira, P. R. R.; Ferreira, E. Org. Lett. 1999, 1, 1335.

7. (a) Almendras, P.; Gruttadauria, M.; Helliwell, M.; Thomas, E. J. J. Chem. Soc., Perkin Trans 1 1997, 2549. (b) Almendras, P.; Thomas, E. J. J. Chem. Soc., Perkin Trans 1 1997, 2561. (c) Thomas, E. J. Chem. Commun. 1997, 411.

8. (a) Keck, G. E.; Abbot, D. E. Tetrahedron Lett. 1984, 25, 1883. (b) Keck, G. E.; Castellino, S. J. Am. Chem. Soc. 1986, 108, 3847. (c) see also: Keck, G. E.; Castellino, S.; Andrus, M. B. In Selectivities in Lewis Acid Promoted Reactions; D. Schinzer, Ed.; NATO ASI Series C; Kluwer Academic:Dordrecht, 1989; Vol. 289, Chapter 5.

9. Yamamoto, Y.; Maeda, N.; Maruyama, K. J. Chem. Soc. Chem. Commun. 1983, 742.

10. (a) Denmark, S. E.; Wilson, T.; Willson, T. M. J. Am. Chem. Soc. 1988, 110, 984. (b) Denmark, S. E.; Weber, E. J.; Wilson, T.; Willson, T. M. Tetrahedron 1989, 45, 1053. (c) Denmark, S. E.; Almstead, N. G. Tetrahedron 1992, 48, 5565. (d) Denmark, S. E.; Almstead, N. G. J. Am. Chem. Soc. 1993, 115, 3133.

11. (a) Dias, L. C.; Giacomini, R. J. Braz. Chem. Soc. 1998, 9, 357. (b) Dias, L. C.; Giacomini, R. Tetrahedron Lett. 1998, 39, 5343.

12. (a) Chérest, M.; Felkin, H.; Prudent, N. Tetrahedron Lett. 1968, 18, 2199. (b) Anh, N. T.; Eisenstein, O. Nouv. J. Chem. 1977, 1, 61. (c) We use the "Felkin" descriptor to refer to the diastereomer predicted by the Felkin-Ahn paradigm. The "anti-Felkin" descriptor refers to diastereomers not predicted by this transition state model.

13. Dias, L. C.; dos Santos, D. R.; Steil, L. J. Tetrahedron Lett. 2003, 44, 6861-6866.

14. (a) Gage, J. R.; Evans, D. A. Org. Synth. 1990, 68, 83. (b) Evans, D. A.; Bartroli, J.; Shih, T. L. J. Am. Chem. Soc. 1981, 103, 2127. (c) Evans, D. A.; Taber, T. R. Tetrahedron Lett. 1980, 21,4675 . 
15. Evans, D. A.; Downey, C. W.; Shaw, J. T.; Tedrow, J. S. Org. Lett. 2002, 4, 1127.

16. Evans, D. A.; Dart, M. J.; Duffy, J. L.; Yang, M. G. J. Am. Chem. Soc. 1996, 118, 4322.

17. We have recently described a very efficient and synthetically useful 1,4-anti-1,5-anti boronmediated aldol reaction of chiral $\alpha$-methyl- $\beta$-alkoxy methyl ketone with achiral aldehydes: Dias, L. C.; Baú, R. Z.; de Sousa, M. A.; Zukerman-Schpector, J. Org. Lett. 2002, 4, 4325.

18. (a) Vacca, J. P.; Condra, J. H. Drug Discov. Today 1997, 2, 261. (b) Steele, F. R. Nature Med. 1996, 2, 257. (c) Huff, J. R. J. Med. Chem. 1991, 34, 2305. (d) Prasad, J.V.N.V.; Rich, D. H. Tetrahedron Lett. 1990, 31, 1803.

19. Tomasselli, A. G.; Heinrikson, R. L. Biochim. Biophys. Acta 2000, 189.

20. For a comparative quantitative structure-activity relationship study on anti-HIV drugs, see: Garg, R.; Gupta, S. P.; Gao, H.; Babu, M. S.; Debnath, A. K.; Hansch, C. Chem. Rev. 1999, 99, 3525.

21. For the synthesis of analogues of L-685,434, see: (a) Litera, J.; Budesinsky, M; Urban, J.; Soucek, M. Collect. Czech. Chem. Commun. 1998, 63, 231. (b) Litera, J.; Weber, J.; Krizova, I.; Pichova, I.; Konvalinka, J.; Fusek, M.; Soucek, M. Collect. Czech. Chem. Commun. 1998, 63, 541. (c) Evans, B. E.; Rittle, K. E.; Homnick, C. F.; Springer, J. P.; Hirshfield, J.; Veber, D. F. J. Org. Chem. 1985, 50, 4615.

22. Dias, L. C.; Meira, P. R. R. Synlett 2000, 37.

23. Dias, L. C.; Ferreira, E. Tetrahedron Lett. 2001, 42, 7159.

24. Gryko, D.; Chalko, J.; Jurczak, J. Chirality 2003, 15, 514.

25. For a review of the synthesis of vicinal aminoalcohols, see: Bergmeier, S. C. Tetrahedron 2000, 56, 2561.

26. For a review about recent advances in the synthesis of peptides, see: Nájera, C. Synlett 2002, 1388.

27. Benedetti, F.; Miertus, S.; Norbedo, S.; Tossi, A.; Zlatoidzky, P. J. Org. Chem. 1997, 62, 9348.

28. de Clercq, E. Pure Appl. Chem. 2001, 73, 55.

29. Shearman, M. S.; Beher, D.; Clarke, E. E.; Lewis, H. D.; Harrison, T.; Hunt, P.; Nadin, A.; Smith, A. L.; Stevenson, G.; Castro, J. L. Biochemistry 2000, 39, 8698.

30. Nadin, A.; López, J. M. S.; Neduvelil, J. G.; Thomas, S. R. Tetrahedron 2001, 57, 1861.

31. Dias, L. C.; Ferreira, A. A.; Diaz, G. Synlett 2002, 1845.

32. Dias, L. C.; Diaz, G.; Ferreira, A. A.; Meira, P. R. R.; Ferreira, E. Synthesis 2003, 4, 603.

33. Includes only spectroscopic data for compounds not described before. 